\title{
Complex and segmental uniparental disomy updated
}

\section{Kotzot}

Correspondence to:

Dr D Kotzot, Division of Clinical Genetics, Department of

Medical Genetics, Molecular and Clinical Pharmacology,

Schoepfstr. 41, A-6020

Innsbruck, Austria;

DieterKotzot@gmx.de

Received 26 January 2008 Revised 25 March 2008

Accepted 26 March 2008

Published Online First

4 June 2008

\section{ABSTRACT \\ Objective: To review all cases with segmental and/or complex uniparental disomy (UPD) and to discuss the impact of these cases on medical genetics.}

Design: Searching for published reports in PubMed and in the abstract books of the annual meetings of the American Society of Human Genetics and the European Society of Human Genetics up to March 2008.

Results: In total, 26 cases with segmental UPD and a normal karyotype, 38 cases with UPD of a whole chromosome and a simple reciprocal or non-homologous Robertsonian translocation, four cases each with two isochromosomes and UPD of the short arm isochromosome and opposite UPD of the long arm isochromosome, three cases with UPD and an isochromosome of the short arm and the long arm of a metacentric or a submetacentric chromosome, one case with maternal UPD and an isochromosome 8 associated with a homozygous deletion (8) (p23.3pter), 42 cases with UPD and an isochromosome of the long arm of an acrocentric chromosome, 33 cases with UPD and a supernumerary marker or ring chromosome, 17 cases with UPD of a whole or parts of a chromosome and a complex karyotype, 13 cases with most likely mosaicism for genome wide paternal UPD, and three cases with most likely mosaicism for genome wide maternal UPD were found.

Conclusion: This update shows that, in particular, the number of reported cases with segmental UPD or UPD associated with a marker chromosome clearly increased within the last few years, and that the investigation of both parents in cases with homozygosity of an autosomal recessively inherited mutation in some cases might help improve genetic counselling, resulting in a reduced recurrence risk in the case of UPD. Moreover, cases with segmental or complex UPD show that meiosis and early postzygotic mitoses seem to be more complex events than previously thought. For the formation of all kinds of segmental or complex UPD or genome wide UPD mosaicism, always a fortunate co-occurrence of meiotic or mitotic recombination, abnormal segregation, and subsequent correction are necessary. No case of recurrence has been reported until now. Therefore, in subsequent pregnancies invasive prenatal diagnosis is not necessarily indicated.

Seven years ago, in this journal I published a review entitled "Complex and segmental uniparental disomy (UPD) - review and lessons from rare chromosomal complements. ${ }^{1}$ One year later I discussed the problem of a supernumerary marker chromosome (SMC) associated with UPD of the same chromosome in more detail. ${ }^{2}$ In 2001, 12 cases with segmental UPD associated with a cytogenetically normal karyotype, ${ }^{3-14}$ 22 cases with UPD of a whole chromosome and a simple reciprocal or non-homologous Robertsonian translocation, ${ }^{15-36} 45$ cases with UPD and a cytogenetically defined isochromosome, ${ }^{16}{ }^{37-76}$ and 21 cases with
UPD of parts of a whole chromosome and a complex chromosomal rearrangement ${ }^{77-93}$ were found in the literature. Meanwhile, the number of patients in all groups has increased.

Therefore, all cases with complex or segmental UPD published in PubMed or in the abstract books of the annual meetings of the American and the European Societies of Human Genetics up to March 2008 were reviewed again. In addition, new findings in UPD research will be discussed comprehensively. As in the first paper, segmental UPD will be defined as UPD of a part of one chromosome (interstitial or telomeric) together with biparental inheritance of the rest of this pair of chromosomes and a normal karyotype (fig 1A,B). Complex UPD will now be subdivided into five groups: (a) UPD of a whole chromosome associated with a "simple" translocation or a Robertsonian translocation of two non-homologous acrocentric chromosomes (fig 1C,D); (b) UPD associated with two isochromosomes, each one made of the short and long arms of a non-acrocentric chromosome (fig $1 \mathrm{E}, \mathrm{F}$ ) or with a Robertsonian translocation between homologous acrocentric chromosomes (fig 1G); (c) UPD of a whole chromosome associated with a supernumerary marker or ring chromosome (fig 1H); (d) "sensu strictu" complex UPD defined as UPD of a part or of a whole chromosome directly involved in or associated with a structural and/or numeric chromosomal complement other than (a) or (b); and (e) most likely mosaicism for genome wide maternal or paternal UPD (fig 1E). Figures explaining the formation of segmental UPD, UPD associated with an isochromosome, and UPD associated with an SMC will be provided in the supplemental material, as already published in the 2001 paper.

Basic knowledge on UPD includes the following points: First, uniparental disomy is defined as the inheritance of both homologues of a pair of chromosomes from one parent only. Second, heterodisomy means that both parental homologues are present, while isodisomy refers to the presence of two copies of one parental homologue. Third, problems associated with UPD are trisomy mosaicism, homozygosity of autosomal recessively inherited mutations, Romozygosity of X-chromosomally inherited disorders in women, and aberrant genomic imprinting. Finally, mechanism of formation of UPD of a whole chromosome are trisomy or monosomy rescue, gamete complementation, and post-fertilisation error. The concept of UPD was introduced by theoretical considerations in medical genetics by Eric Engel in $1980 .{ }^{94}$ The first proven case of whole chromosome UPD was published in 1987.70 Interestingly, according to our definition, the $45, \mathrm{XX}, \mathrm{t}(21 \mathrm{q} ; 21 \mathrm{q})$ karyotype of this case also represents the first reported case of a complex UPD. 
Figure 1 Diagrams of segmental and complex uniparental disomy (UPD): (A) telomeric segmental UPD; (B) interstitial segmental UPD; (C) UPD associated with a "simple" translocation; (D) UPD associated with a translocation of nonhomologous acrocentric chromosomes; (E) pat/mat UPD associated with two isochromosomes, one of the short and one of the long arm of a non-acrocentric chromosome; (F) UPD associated with two isochromosomes of the same parental non-acrocentric chromosome; (G) UPD associated with a translocation between two homologous acrocentric chromosomes; (H) "sensu strictu" complex UPD in the instance of an additional marker chromosome; and (I) genome wide UPD mosaicism (here the symbols represent not a chromosome but a haploid genome).
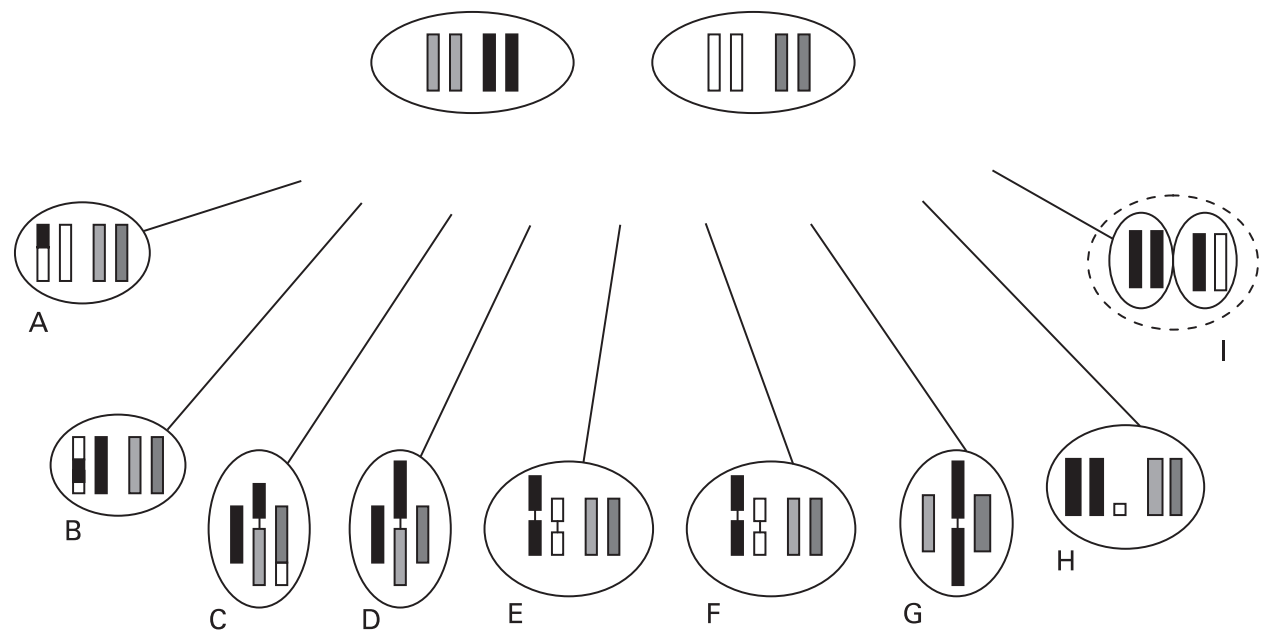

Table 1 Segmental uniparental disomy associated with a cytogenetically normal karyotype

\begin{tabular}{|c|c|c|c|c|c|c|c|c|c|c|}
\hline Karyotype & UPD (segment) & H & 1 & $\Sigma$ & H & I & $\Sigma$ & $?$ & Associated AR inherited disorder & Reference \\
\hline $46, X ?$ & (1)(p31) & & 1 & 1 & & & & & Leber amaurosis & 96 \\
\hline $46, X X$ & $(1)(p 22.1)$ & & 1 & 1 & & & & & Stargardt disease & 97 \\
\hline $46, X Y$ & (1)(p11.2->qter) & & 1 & 1 & & & & & Hutchinson-Gilford progeria & 98 \\
\hline $46, X Y$ & (2)(p12p11.2) & & 1 & 1 & & & & & Congenital hypothyroidism & 99 \\
\hline $46, X X$ & $(2)(p 16)$ & & 1 & 1 & & & & & & 3 \\
\hline $46, X X$ & (2)(q37.3->qter) & & 1 & 1 & & & & & Hyperoxaluria type I & 100 \\
\hline $46, X ?$ & $(4 p)$ & & & & & & & $1 \times 1$ & DIDMOAD & 4 \\
\hline $46, X Y$ & (4)(q21q35) & & 1 & 1 & & & & & Abetalipoproteinaemia & 5 \\
\hline $46, X X$ & $5 q 32$ & & 1 & 1 & & & & & Netherton syndrome & 102 \\
\hline $46, X X$ & $5 q 32->$ qter & & 1 & 1 & & & & & & 103 \\
\hline $46, X X$ & $(6)(\mathrm{p} 21.3)$ & & & & & 1 & 1 & & 21-OH-Deficiency & 6 \\
\hline $46, X ?$ & $7 q$ & 1 & & 1 & & & & & Cystic fibrosis & 107 \\
\hline $46, X ?$ & $7 q$ & & 1 & 1 & & & & & & 108 \\
\hline $46, X ?$ & $\operatorname{mos}(11)(\mathrm{p} 15->$ pter $)$ & & & & & * & & & & 95 \\
\hline $46, \mathrm{XN}$ & $11 \mathrm{p} 15.1$ & & & & & 1 (mos) & & & & 113 \\
\hline $46, X X$ & 11 q23.3->qter & & & & & & & 1 & & 109 \\
\hline $46, X Y$ & 14q12-qter & & & & & 1 & 1 & & & 110 \\
\hline $46, X ?$ & $(14)(q 12 q 24.3)$ & 1 & & 1 & & & & & & 10 \\
\hline $46, X X$ & 14q23.3->qter & & & & & 1 & 1 & & & 111 \\
\hline $46, X Y$ & $(15)(q 12 q 13)$ & 1 & & 1 & & & & & & 112 \\
\hline $46, X Y$ & $17 q 25->$ qter & 1 & & 1 & & & & & & 13 \\
\hline $46 \mathrm{XY}$ & $20 q$ & & & & & 1 & 1 & & & 14 \\
\hline
\end{tabular}

\section{SEGMENTAL UPD ASSOCIATED WITH A NORMAL KARYOTYPE}

Apart from mosaicism for paternal UPD of the chromosomal segment $11 \mathrm{p} 15->$ pter, which is found in 10-20\% of cases affected by Beckwith-Wiedemann syndrome (BWS), ${ }^{95}$ revised 11 cases with segmental UPD and a normal karyotype were reported up to 2001 (table 1). $\cdot^{3-8}{ }^{10-14}$ Meanwhile, several new cases have been published. ${ }^{96-113}$ One case ${ }^{9}$ was corrected after testing more markers, and was now assumed to result from a microsatellite marker mutation. ${ }^{114}$ Most of the new cases were ascertained by homozygosity for a mutation causing an autosomal recessively inherited disorder and present in only one parent. ${ }^{96-102} 105107$ Nine cases were detected by other 
approaches. One case of childhood onset schizophrenia associated with telomeric segmental isodisomy $5 \mathrm{q}$ was found during a whole genome screening of a cohort of patients with childhood onset schizophrenia. ${ }^{103}$ Zühlke et al described a case with spinocerebellar ataxia type 17 and a homozygous repeat expansion in the TBP gene. ${ }^{104}$ The unavailability of parental DNA questions the results, but both parents were noted as being healthy and the identical mutation event in maternal and paternal meiosis seems highly unlikely. In a study on the relevance of UPD for spontaneous abortions Tsukishiro et al found telomeric maternal isodisomy $7 \mathrm{q} .{ }^{106}$ Genes on $7 \mathrm{q}$ are considered to be relevant for autism spectrum disorder; so in a study on 60 pedigrees each with at least one individual affected by autism spectrum disorder, one case of not exactly defined interstitial maternal UPD $7 q$ was identified. ${ }^{108}$ Haag et al assumed UPD 11q23.3->qter in the mother of two brothers with Jacobson syndrome due to an identical deletion 11q23$>$ qter, but grandparents were not available. ${ }^{109}$ Two new cases of segmental paternal UPD 14, one with telomeric isodisomy 14q23.3-> qter and a second with isodisomy 14q12->qter, show the typical clinical picture of paternal UPD $14 .{ }^{110} 111$ Furthermore, Nazarenko et al reported the only case so far of Prader-Willi syndrome (PWS) with segmental maternal heterodisomy $15 q 12->q 13 .{ }^{112}$ Finally, Hussain et a ${ }^{113}$ described a case with mosaic interstitial paternal isodisomy 11 p15.1 and atypical diffuse congenital hyperinsulinism.

\section{UPD OF A WHOLE CHROMOSOME ASSOCIATED WITH A "SIMPLE" TRANSLOCATION OR A ROBERTSONIAN TRANSLOCATION}

In 2001, revised 18 cases with UPD of a whole chromosome and a "simple" reciprocal translocation and four cases with UPD of a whole chromosome and a non-homologous Robertsonian translocation were found in the literature (table 2)..$^{15-36}$ Meanwhile, the figure increased to $38 .{ }^{115-128}$ Cases of UPD associated with a non-homologous Robertsonian translocation demonstrated by molecular methods were not considered, if no information on parental origin was given. Apart from one case, who was described as a balanced 3/15 translocation of maternal origin associated with maternal uniparental heterodisomy 15 resulting in PWS, ${ }^{127}$ all new cases showed non-homologous Robertsonian translocations. Now, there is one case with a 13/ 14 translocation and maternal UPD 13 and there are four cases with a 13/14 translocation and a paternal UPD 13, 20 cases with a Robertsonian translocation including chromosome 14 and another D or G group chromosome and maternal UPD 14 $(16 \times 13 / 14$ translocation, $2 \times 14 / 15,3 \times 14 / 21$, and $1 \times 14 / 22)$, and five cases with a $13 / 15$ or a $14 / 15$ translocation and maternal UPD 15 reported (table 3). Three of the recently reported maternal UPD 14 cases are de novo. ${ }^{115} 116121$ Only five out of a total of 33 non-homologous Robertsonian translocations are associated with paternal UPD (4× UPD 14 associated with a 13/ 14 translocation and $1 \times$ UPD 15 associated with a 14/15 translocation) (table 2). In both maternal and paternal UPD cases the 13/14 translocations are overrepresented (16 out of 25 in maternal UPD and four out of five in paternal UPD) with a new overrepresentation of UPD 14 (table 2). The phenotype of maternal UPD 14 is characterised by pre- and postnatal growth retardation, early onset of puberty, advanced bone age, and minor dysmorphisms. In paternal UPD 14 polyhydramnion, skeletal anomalies, contractures, and dysmorphic features are typical findings. All reported paternal UPDs associated with a non-homologous Robertsonian translocation are paternally inherited. In the maternal heterodisomy group nine patients with a Robertsonian translocation were maternally inherited. $^{22} 242528$ 118-120124 125 PWS due to maternal UPD 15 was reported in three families with a maternal 14/15 translocation, ${ }^{34} 35128$ and in two families with a maternal 13/15 translocation. $^{32}{ }^{33}$ So far, only one case of Angelman syndrome due to paternal UPD 15, associated with a Robertsonian translocation, has been described. ${ }^{124}$

\section{UPD OF A WHOLE CHROMOSOME ASSOCIATED WITH A CYTOGENETICALLY DEFINED ISOCHROMOSOME}

UPD associated with an isochromosome and a correct amount of genetic material is possible (a) in the case of an isochromosome replacing the two homologues of a pair of acrocentric chromosomes, or (b) by isochromosomes both of the short arm and of the long arm of a non-acrocentric chromosome. Fortyfive patients falling into this category have been described up to 2001 (table 3). ${ }^{16}{ }^{37-76}$ Three of these cases carried an isochromosome of the short arm and an isochromosome of the long arm, the isochromosomes being of opposite parental origin. ${ }^{38} 4243$ Meanwhile, only seven new cases were reported. ${ }^{129-135}$ These cases comprise five patients with an isochromosome $14 \mathrm{q},{ }^{129-133}$ one patient with an isochromosome $15 \mathrm{q},{ }^{134}$ and one healthy man with a paternal isodisomic $\mathrm{i}(2 \mathrm{p})$ and a maternal heterodisomic $\mathrm{i}(2 \mathrm{q}) .{ }^{135}$ The finding of heterodisomy in the latter

Table 2 Uniparental disomy of a whole chromosome associated with a "simple" translocation (non-homologous Robertsonian translocations included)

\begin{tabular}{|c|c|c|c|c|c|c|c|c|c|c|}
\hline \multirow[b]{2}{*}{ Karyotype } & \multirow[b]{2}{*}{ UPD } & \multicolumn{4}{|c|}{ Maternal UPD } & \multicolumn{4}{|c|}{ Paternal UPD } & \multirow[b]{2}{*}{ Reference } \\
\hline & & H & $I$ & $?$ & $\Sigma$ & H & 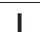 & $?$ & $\Sigma$ & \\
\hline $46, X X, t(7 ; 16)(q 11.2 q 22) m a t$ & 7 & 1 & & & 1 & & & & & 15 \\
\hline $45, X N, t(13 ; 14)$ & 14 & 12 & 3 & 1 & 16 & 3 & 1 & & 4 & $17-27,115-123$ \\
\hline $45, X X, t(14 ; 15)$ & 14 & 1 & & 1 & 2 & & & & & 124 \\
\hline $45, X X, t(14 ; 21)$ & 14 & 3 & & & 3 & & & & & $28,120,126$ \\
\hline $45, X Y, t(8 ; 15)(p 23.3 q 11)$ pat & 15 & & & & & 1 & & & 1 & 31 \\
\hline $46, X X, t(8 ; 15)(q 24.1 q 21.2)$ mat & 15 & 1 & & & 1 & & & & & 127 \\
\hline $45, \mathrm{XN}, \mathrm{t}(13 ; 15)$ & 15 & 2 & & & 2 & & & & & 32,33 \\
\hline $45, X ?, t(14 ; 15)$ & 15 & 3 & & & 3 & & & 1 & 1 & $34,35,124,128$ \\
\hline $46, X Y, t(10 ; 16)(q 11.2 q 11.1)$ & 16 & 1 & & & 1 & & & & & 36 \\
\hline$\Sigma$ & & 26 & 3 & 2 & 31 & 5 & 1 & 1 & 7 & \\
\hline
\end{tabular}

$\mathrm{H}$, heterodisomy; I, isodisomy; UPD, uniparental disomy. 
Table 3 Uniparental disomy associated with an isochromosome defined cytogenetically

\begin{tabular}{|c|c|c|c|c|c|c|c|c|}
\hline \multirow[b]{2}{*}{ Karyotype } & \multirow[b]{2}{*}{ UPD } & \multicolumn{3}{|c|}{ Maternal UPD } & \multicolumn{3}{|c|}{ Paternal UPD } & \multirow[b]{2}{*}{ Reference } \\
\hline & & H & 1 & $\Sigma$ & H & I & $\Sigma$ & \\
\hline $46, X X, i(1 p), i(1 q)$ & 1 & & & & & 1 & 1 & 37 \\
\hline $46, X N, i(2 p), i(2 q)$ & 2 & $1(2 q)$ & $1(2 q)$ & & & $2(2 p)$ & & 38,145 \\
\hline $46, X X, i(2 p), i(2 q)$ & 2 & & 2 & 2 & & & & 39,40 \\
\hline $46, X X, i(4 p), i(4 q)$ & 4 & & 1 & 1 & & & & 41 \\
\hline $46, X ?, i(7 p), i(7 q)$ & 7 & & $2(7 q)$ & & & $2(7 p)$ & & 42,43 \\
\hline $\begin{array}{l}45, \mathrm{XX}_{1}-8,-8,+\mathrm{psu} \operatorname{dic}(8)(\mathrm{p} 23.3) \\
\text { [associated del(8)(p23.3pter)] }\end{array}$ & 8 & 1 & & 1 & & & & 44 \\
\hline $46, X X, i(9 p), i(9 q)$ & 9 & & 1 & 1 & & & & 45 \\
\hline $45, X N, i(13 q)$ & 13 & & 2 & 2 & 1 & 4 & 5 & $16,46-51$ \\
\hline $45, X N, i(14 q)$ & 14 & 8 & 4 & 12 & & 4 & 4 & $16,21,28,52-59,129-133$ \\
\hline $45, X N, i(15 q)$ & 15 & & 5 & 5 & & 6 & 6 & $53,60-68,134$ \\
\hline $45, X Y, i(21 q)$ & 21 & 1 & 1 & 2 & & 2 & 2 & $53,70-72$ \\
\hline $45, X N, i(22 q)$ & 22 & & 3 & 3 & & 1 & 1 & $73-76$ \\
\hline$\Sigma$ & & $10(+1)$ & $19(+3)$ & 29 & 1 & $18(+4)$ & 19 & \\
\hline
\end{tabular}

$\mathrm{H}$, heterodisomy; I, isodisomy; UPD, uniparental disomy.

indicates an initial meiotic event. Up to now, 12 cases with a cytogenetically defined isochromosome 14q and maternal UPD 14 ( $8 \times$ isodisomy and $4 \times$ heterodisomy), ${ }^{21}{ }^{49} 52-58$ 129-131 and four cases with a isochromosome $14 \mathrm{q}$ and paternal UPD 14 have been reported. ${ }^{16} 59132133$ All isochromosomes $15 \mathrm{q}$ are true isochromosomes. Because of some errors in the 2001 list, now altogether only 42 cases with a cytogenetically defined isochromosome and UPD, and four cases with two isochromosomes and partial maternal and partial paternal UPD 4243135 are known.

\section{UPD OF A WHOLE CHROMOSOME ASSOCIATED WITH A MARKER OR A RING CHROMOSOME}

In table 4 of the 2001 review (UPD of a part or of a whole chromosome directly involved in or associated with a complex structural and/or numeric chromosomal complement), only 13 cases with a supernumerary marker or ring chromosome were listed. ${ }^{35} 697778$ 80-85 88 Now, these cases and, to the best of my knowledge, 20 new cases ${ }^{136-153}$ are discussed separately (table 4).

Röthlisberger et al reported on a 6-year-old girl with mental retardation, microcephaly, facial dysmorphisms, a de novo 47,XX,der(1)(p21.1q12)/46,XX karyotype, and maternal heterodisomy $1 .{ }^{136}$ The facts that the derivative chromosome 1 carried euchromatic material and that maternal UPD 1 per se is without a phenotype, ${ }^{154}$ makes UPD unlikely to be causative for the clinical findings. A case of maternal uniparental heterodisomy 7 associated with an SMC(7) in 36\% of cells exhibited SilverRussell syndrome. ${ }^{137}$ Anderlid et al reported on a girl with mental retardation, no obvious dysmorphisms, a de novo 47,XX,r(9)(p10p12) karyotype, and maternal uniparental heterodisomy 9. ${ }^{139}$ Von Eggeling et al described a healthy newborn aged 6 weeks with a 47,XX, mar(12)/46,XX karyotype and maternal heterodisomy $12 .{ }^{140}$ So, maternal UPD 12 appears also to be without phenotypical effects. Furthermore, three cases with UPD 14 and mosaicism for an SMC(14) were reported. ${ }^{120} 141$ The first was a female with the typical findings of paternal UPD $14 .{ }^{141}$ The second and the third were males and showed maternal heterodisomy $14 .{ }^{120}$ Clinical features of the second included symmetrical growth retardation, retarded bone age, small hands and feet, muscular hypotonia, delay of motor development, recurrent middle ear infections, and mild facial dysmorphisms. ${ }^{120}$ For the third only asymmetric growth retardation at birth were reported. ${ }^{120}$ The number of cases with UPD 15 associated with a der(15) increased to $17 . .^{35} 69$ 80-85 144-149 In three of these cases the der(15) was defined as del(15q) and in one patient as an $r(15) .{ }^{35}{ }^{146-148}$ All other SMCs(15) have an inv dup(15). In an abstract, Kron et al reported on a plagiocephalic but otherwise unremarkable newborn with a 47,XY,der(16)(p11.21;q11.1)/46,XY karyotype and maternal heterodisomy $16 .{ }^{151}$ Vendetti et al reported on a 9-month-old boy with a complex heart defect, 13 ribs on the left, partial ileal and total colonic Hirschsprung disease, central nervous system abnormalities, a 45,XY,psu $\operatorname{dic}(20 ; 20)(\mathrm{p} 13 / \mathrm{p} 13) / 4645, \mathrm{XY}$,psu $\operatorname{dic}(20 ; 20)(\mathrm{p} 13 ; \mathrm{p} 13)+20$ karyotype, and maternal uniparental isodisomy $20{ }^{155}$ This case was cited in the 2001 review with an abstract. ${ }^{87}$ Bartels et al described a healthy 18-month-old girl with confined placental mosaicism of trisomy 22 and a small SMC(22) and maternal UPD 22 in blood. ${ }^{153}$ In a systematic search for SMCs, Bartsch et al found one case of mosaicism for inv $\operatorname{dup}(22)$ and maternal UPD 22 out of 43273 prenatal samples. ${ }^{152}$ Also a de novo SMC (idic(22)) was reported in a child with PWS due to maternal uniparental heterodisomy $15 .{ }^{150}$ Together with a case of PWS due to maternal UPD 15 associated with a SMC $(X){ }^{80}$ now two cases with maternal UPD 15 and an SMC of another chromosome have been reported. Unfortunately, in both cases the parental origin of the SMC was not determined.

\section{UPD OF A PART OR OF A WHOLE CHROMOSOME DIRECTLY INVOLVED IN OR ASSOCIATED WITH A COMPLEX STRUCTURAL AND/OR NUMERIC CHROMOSOMAL COMPLEMENT}

Up to 2001, only nine cases with a whole chromosome directly involved in or associated with a complex structural and/or numerical chromosomal complement were reported (UPD with a supernumerary marker or ring chromosome excluded) (table 5). ${ }^{79} 868789-93$ Meanwhile, several cases, which were not listed or wrongly listed in the 2001 paper came to my attention. ${ }^{29}$ 155-161 Among others there are three cases with non-disjunction of two chromosomes and segmental UPD. First, Starke et al reported on a 2-month-old boy with free trisomy 21 due to maternal non-disjunction, mosaicism for an SMC originating from chromosome 4, and maternal uniparental isodisomy $4 \mathrm{p} 15-16 .{ }^{156}$ The boy has the clinical features of trisomy 21 but no additional anomalies. Parker et al reported on a patient with a Klinefelter karyotype due to maternal nondisjunction of the X chromosome, mosaicism for an SMC(6), and maternal UPD $6 .{ }^{157}$ Finally, Tsai et al described a child with Angelman syndrome due to paternal uniparental heterodisomy 15 associated with a paternal 13/15 translocation, segmental 
Table 4 Uniparental disomy of a whole chromosome associated with a marker or a ring chromosome

\begin{tabular}{|c|c|c|c|c|c|c|c|c|c|c|}
\hline \multirow[b]{2}{*}{ Karyotype } & \multirow[b]{2}{*}{ UPD } & \multicolumn{4}{|c|}{ Maternal UPD } & \multicolumn{4}{|c|}{ Paternal UPD } & \multirow[b]{2}{*}{ Reference } \\
\hline & & H & I & $?$ & $\Sigma$ & H & I & $?$ & $\Sigma$ & \\
\hline $47, X X, \operatorname{der}(1)(p 21.1 ; q 12) / 46, X X$ & 1 & 1 & & & 1 & & & & & 136 \\
\hline $47, \mathrm{XX},+\mathrm{r}(6) / 46, \mathrm{XX}$ & 6 & & 1 & & 1 & & & & & 77 \\
\hline $47, X Y,+\operatorname{mar} / 46, X Y$ & 7 & 1 & & & 1 & & & & & 137 \\
\hline 47,XX,UPD(7)mat,+r(7)pat/46,XX & 7 & 1 & 1 & & 2 & & & & & 78,138 \\
\hline $47, X X, r(9) / 46, X X$ & 9 & 1 & & & 1 & & & & & 139 \\
\hline $47, \mathrm{XX},+\operatorname{mar} / 46, \mathrm{XX}$ & 12 & 1 & & & 1 & & & & & 140 \\
\hline $47, X ?,+$ mar & 14 & 2 & & & 2 & & & & & 120 \\
\hline $47, X X,+m a r / 46, X X$ & 14 & & & & & & 1 & & 1 & 141 \\
\hline 46,XN/47,XN,+idic(15) & 15 & 3 & 2 & 5 & 10 & 1 & 1 & 1 & 3 & $\begin{array}{l}65,69,80-84,143-145, \\
149\end{array}$ \\
\hline $47, X Y$, del $(15) / 46, X Y$ & 15 & 3 & & & 3 & & & & & $35,146,147$ \\
\hline $47, X Y, r(15) / 46, X Y$ & 15 & 1 & & & 1 & & & & & 148 \\
\hline $47, X X, \operatorname{mar}(X) / 46, X X$ & 15 & & & 1 & 1 & & & & & 80 \\
\hline $47, X Y,+\operatorname{idic}(22)(q 11.1) / 46, X Y$ & 15 & 1 & & & 1 & & & & & 150 \\
\hline $47, X Y, \operatorname{der}(16)(p 1.21 q 11.1)$ & 16 & & & & & & & 1 & 1 & 151 \\
\hline $47, X Y,+\operatorname{mar}(20)(p 11.2 q 11.2 / 46, X Y$ & 20 & 1 & & & 1 & & & & & 88 \\
\hline $47, X Y$, mar & 22 & 1 & & & 1 & & & & & 152 \\
\hline $47, \mathrm{XX},+\mathrm{mar} / 47, \mathrm{XX},+22 / 46, \mathrm{XX}$ & 22 & 1 & & & 1 & & & & & 153 \\
\hline$\Sigma$ & & 18 & 4 & 6 & 28 & 1 & 2 & 2 & 5 & \\
\hline
\end{tabular}

$\mathrm{H}$, heterodisomy; I, isodisomy; UPD, uniparental disomy.

paternal isodisomy 13 , and features of trisomy $13 .{ }^{160}$ The mechanism of formation of the aberrant karyotype in all three cases was most likely non-disjunction for two different chromosomes in meiosis followed by either two breaks (one on the short and one on the long arm of the unseparated chromosomes) subsequent to a mitotic recombination between one maternal and one paternal chromosome, or trisomy or monosomy rescue. Park et al described a 17-year-old boy with PWS caused by maternal heterodisomy 15 and a $47, X Y,+\operatorname{der}(15) \mathrm{t}(3 ; 15)(\mathrm{p} 25 ; \mathrm{q} 11.2)$ karyotype due to an adjacent one segregation of a balanced paternal 46,XY,t(3;15)(p25;q11.2) translocation. ${ }^{29}$ Bartsch et al reported on two cases with UPD 21 and chromosomal rescue over time. ${ }^{161}$ The first child revealed a de novo 46,XX[1]/46,XX,r(21)[99]/45,XX,-21[104] karyotype at the age of 1 month and a 46,XX[198]/45,XX,-21[2] karyotype at the age of 49 months. The second case showed a de novo 46,XX,(21q-)/[10]/45,XX,-21[90] karyotype as a newborn and a $46, X X[99] / 46, X X,(21 q)$ [1] karyotype at the age of 16 years. In both cases the karyotype in fibroblast was nearly constant over the time. Both children exhibited severe mental retardation and various malformations and dysmorphic features.

\section{GENOME WIDE MATERNAL OR PATERNAL UPD COMBINED WITH BIPARENTAL INHERITANCE)}

Up to now, 10 cases with most likely genome wide maternal or paternal UPD in a proportion of cells/tissues, biparental disomy

Table 5 Uniparental disomy of parts or of a whole chromosome associated with a complex chromosomal rearrangement (isochromosomes and supernumerary marker chromosomes excluded)

\begin{tabular}{|c|c|c|c|c|c|c|c|c|c|c|}
\hline \multirow[b]{2}{*}{ Karyotype } & \multirow[b]{2}{*}{ UPD } & \multicolumn{4}{|c|}{ Maternal UPD } & \multicolumn{4}{|c|}{ Paternal UPD } & \multirow[b]{2}{*}{ Reference } \\
\hline & & H & I & $?$ & $\Sigma$ & H & 1 & $?$ & $\Sigma$ & \\
\hline $48, X Y,+21,+\operatorname{mar}^{28} / 47, X Y,+21^{7}$ & $(4)(p 15 ; p 16)$ & & 1 & & 1 & & & & & 156 \\
\hline $47, X X Y$ & 6 & & & & & 1 & & & 1 & 158 \\
\hline $47, X X X$ & 6 & & & & & & 1 & & 1 & 159 \\
\hline $\begin{array}{l}45, \mathrm{XX},-8,-8,+ \text { psu dic(8)(p23.1p23.3) [del(8) } \\
\text { (p23.1pter), del(8)(p23.3pter)] }\end{array}$ & (8)(p23.1qter) & 1 & & & 1 & & & & & 79 \\
\hline $45, X Y, t(13 ; 15)$ & 15 and $(13)(q 14.3)$ & & & & & & 1 & & 1 & 160 \\
\hline $46, X Y, \operatorname{der}(1) t(1 ; 16)(p 36.3 p 13.1) / 46, X Y$ & (16)(p13.1qter) & & 1 & & 1 & & & & & 86 \\
\hline $\begin{array}{l}\text { 45,XY,psu dic }(20 ; 20)(p 13 p 13) / 46, X Y, p s u d i c \\
(20 ; 20)(p 13 p 13),+20\end{array}$ & 20 & & & & & & & 1 & 1 & 155 \\
\hline $46, X X, r(21) / 46, X X$ & 21 & & & & & & & 1 & 1 & 161 \\
\hline $46, X X, 21 q-/ 45, X X,-21 / 46, X X$ & 21 & & 1 & & 1 & & & & & 161 \\
\hline $47, X X,+\operatorname{der}(22), t(11 ; 22),(q 23 q 11) \mathrm{dn}$ & (22)(q11.2qter) & 1 & & & 1 & & & & & 89 \\
\hline $45, X / 46, X, \operatorname{del}(X)(q 21.3 q \operatorname{ter}) / 46, X, r(X)$ & $(\mathrm{X})(\mathrm{pterq} 21.3)$ & 1 & & & 1 & & & & & 90 \\
\hline $45, X, t(X ; Y)(p 22.3 p 11)$ & $(\mathrm{X})(\mathrm{p} 22.3 \mathrm{qter})$ & & & & & & 1 & & 1 & 93 \\
\hline$\Sigma$ & & 5 & 5 & & 10 & 1 & 4 & 2 & 7 & \\
\hline
\end{tabular}

$\mathrm{H}$, heterodisomy; I, isodisomy; UPD, uniparental disomy. 
in various other tissues, and a living child have been reported (table 6). ${ }^{162-170}$ In addition, six cases displayed genome wide paternal UPD in the placenta only. ${ }^{171-174}$ Genotype-phenotype correlation is hampered by mosaicism, but all liveborns resemble in one part or more known imprinting disorders associated with paternal UPD 6, 11p15, 14, 15, and 20. The most impressive case was reported by Bryke et al. ${ }^{164}$ The girl was affected by transient neonatal diabetes mellitus (pat UPD 6), hepatosplenomegaly and limb asymmetry (pat UPD11p15), as well as rib anomalies (pat UPD 14). Muscular hypotonia, seizures, and ataxia (pat UPD 15) were seen in her as well as nodular adrenal hyperplasia (pat UPD 20). Five cases with genome wide paternal UPD in blood showed features of paternal UPD 11p15. ${ }^{162-165}$ In one case the genome wide paternal UPD was restricted to the tumour only. ${ }^{165}$ In another case genome wide paternal UPD was found in up to $60 \%$ of the placenta, hepatic mesenchymal hamartoma, and normal liver tissue. ${ }^{167}$ The three cases with genome wide maternal UPD comprise one case with a 46,XX/46,XY karyotype, a normal male phenotype, and maternal uniparental isodisomy, ${ }^{169}$ and one case with maternal isodisomy in blood, biparental marker inheritance in skin fibroblasts, a 46,XX/46,XY karyotype, left sided hemifacial microsomia, small testes, mild learning difficulties, and intermittent aggressive behaviour. ${ }^{170}$ In addition, there is one case of premature termination of pregnancy with a fetus showing a 46,XX/46,XY karyotype, but an obviously normal male phenotype at least as could be judged by prenatal ultrasound examination. ${ }^{168}$

\section{DISCUSSION}

The mechanism of formation of UPD is an important point when it comes to assessing the risk for adverse outcome (particularly in prenatal diagnosis), not only in most cases of whole chromosome UPD but also in cases with segmental or complex UPD. Apart from trisomy rescue and the rare postfertilisation errors, gamete complementation or monosomy rescue might particularly be assumed in some cases of UPD for an acrocentric chromosome and a non-homologous Robertsonian translocation including this chromosome in the opposite parent. However, so far no case has been proven unambiguously. Therefore, the question of whether, in prenatal diagnosis of Robertsonian translocations, only a UPD of the translocation carrying parent or also the opposite UPD should be investigated, cannot be answered conclusively. In most cases, in practice it will happen anyway by informativity of the markers. According to several retrospective studies the risk for UPD 14 in prenatally diagnosed de novo or familial Robertsonian translocations including chromosome 14 is low. ${ }^{16} 115125175$ Nevertheless, particularly if chorionic villi sampling or amniocentesis have been performed for other reasons, investigation for UPD 14 should be performed in conjunction with adequate genetic counselling, particularly reflecting the variable phenotype of maternal UPD 14. Even much rarer familial reciprocal translocations associated with UPD of a whole chromosome have been described. In such cases, the indication for an invasive prenatal diagnosis should be discussed critically. ${ }^{176}$ So far, no case of a de novo balanced nonRobertsonian translocation associated with UPD of one of the translocation chromosomes has been reported. The case of maternal UPD 16 associated with a 10/16 translocation reported by Wang et $a^{36}$ shows also mosaicism in chorionic villi indicating a trisomy rescue mechanism.

Recurrence risk after birth of a child with segmental or complex UPD seems to be negligible. All mechanisms of

Table 6 Genotypes and phenotypes of cases with genome wide paternal uniparental disomy (UPD) mosaicism

\begin{tabular}{|c|c|c|c|c|c|c|c|}
\hline Phenotype & Karyotype & Blood & CVS & Fibroblasts & Tumour & Specific tissue & Reference \\
\hline $\begin{array}{l}\text { Normal placenta, polyhydramnion, high birthweight, } \\
\text { postnatal growth retardation, hepatosplenomegaly, } \\
\text { hypertrophic cardiomyopythy, umbilical hernia, } \\
\text { hypoglycemia, bilateral phaeochromocytoma, } \\
\text { muscular hypotonia, low average mental } \\
\text { development }\end{array}$ & $46, X X$ & + & & No & + & & 162 (case 1) \\
\hline $\begin{array}{l}\text { Cystic placenta, high birthweight, adrenal cysts, } \\
\text { small umbilical hernia, hyperinsulinaemic } \\
\text { hypoglycaemia, hemangioendothelioma/ } \\
\text { hepatoblastoma, leg hemihypertrophy, linear } \\
\text { hyperpgigmentation, mild developmental delay }\end{array}$ & $46, X X$ & + & & & & & 162 (case 2) \\
\hline Hemihypertrophy, Wilms tumour with pat UPD11p15 & $46, X X$ & No & & & + & Kidney & 163 \\
\hline $\begin{array}{l}\text { Transient neonatal diabetes mellitus, leg } \\
\text { hemihypertrophy, capillary haemangioma, bowed } \\
\text { ribs, muscular hypotonia, developmental delay, } \\
\text { ataxia, seizures, abnormal pigmentation, } \\
\text { hepatosplenomegaly }\end{array}$ & $46, X X$ & + & & & & $\begin{array}{l}\text { Urine, liver, adrenal, } \\
\text { not in buccal cells }\end{array}$ & 164 \\
\hline $\begin{array}{l}\text { Enlarged cystic placenta in one twin, spontaneous } \\
\text { abortion }\end{array}$ & $46, X X / X Y$ & No & & & & & 166 \\
\hline PMD, hepatic mesenchymal hamartoma & $46, X X$ & No & & & + & & 167 \\
\hline $\begin{array}{l}\text { PMD, IUGR, fetal liver cysts and haemangioma, } \\
\text { normal growth and mental development }\end{array}$ & $46, X X$ & No & + & & & & 171 (case 1 ) \\
\hline $\begin{array}{l}\text { PMD, IUGR, normal development, capillary } \\
\text { haemangiomas }\end{array}$ & $46, X X$ & & Mesenchym, vessels & & & Not in trophoblast & 171 (case 2) \\
\hline Dizygotic twin pregnancy, PMD, IUGR, sib healthy & $46, X X$ & & Mesenchym, chorion & & & & 172 (case 1) \\
\hline Dizygotic twin pregnancy, PMD, IUGR, healthy & $46, X X$ & & Mesenchym, chorion & & & & 172 (case 2) \\
\hline Dizygotic twin pregnancy, PMD, IUGR, healthy & $46, X Y$ & & + & & & & 173 \\
\hline PMD, IUGR, healthy & $46, X X$ & & + & & & & 174 \\
\hline
\end{tabular}

AC, amniocentesis; CVS, chorionic villi sampling; IUGR, intrauterine growth retardation; PMD, placental mesenchymal dysplasia. 
formation leading to UPD are so complex, that recurrence is very unlikely. Starting with non-disjunction, germ line mosaicism for a disomic gamete might be possible, but subsequent pregnancies will terminate by spontaneous abortion with high probability.

Most cases of segmental uniparental isodisomy seem to be detected by chance (that is, in the case of homozygosity for an autosomal recessively inherited mutation, which is present in one parent only) or in patients with a phenotype resembling a disorder caused by abnormal genomic imprinting. The hypothesis of a meiotic non-disjunction also as the first step towards segmental isodisomy in most cases is supported by the increasing number of cases with whole chromosome UPD and no phenotype directly related to UPD. ${ }^{154}$ As discussed in the 2001 review, mitotic formation would only be detectable by molecular methods if there is a tissue specific selection or one of the resulting UPDs would be lethal. Therefore, a normal phenotype of individuals with UPD of this chromosome as a whole should exclude lethality of UPD of this segment. Nevertheless, in cases with segmental UPD-particularly if there is a phenotype not to be explained by the UPD-the possibility of presence of low level trisomy mosaicism and its clinical consequences should not be forgotten in genetic counselling. The large number of cases with segmental UPD ascertained by homozygosity of an autosomal recessively inherited mutation underlines the importance of demonstrating the mutation in both parents, as in such cases a lower recurrence risk can be given.

UPD associated with an isochromosome is formed either by: (a) meiotic misdivision at the centromeres resulting in a gamete with an isochromosome, fertilisation by a normal gamete, and subsequent mitotic loss of the homologous chromosome ("trisomy rescue"); or (b) meiotic misdivision and fertilisation by a nullisomic gamete ("gamete complementation"); or (c) mitotic misdivision at the centromeres of sister or non-sister chromatids in a trisomic zygote associated with a subsequent loss of the homologue; or (d) mitotic misdivision at the centromere in a monosomic zygote ("monosomy rescue"). ${ }^{1}$ The time and mechanism of formation of cytogenetically defined isochromosomes of acrocentric chromosomes associated with UPD remains speculative. Except for one case of uniparental heterodisomy, all paternal UPDs display isodisomy. For maternal UPD nine out of 24 cases were isodisomic. Inheritance has been demonstrated for three cases, one with an isochromosome 13q and two with an isochromosome 22q. ${ }^{48} 7475$ Inheritance of isochromosomes with an identical imprint is only possible if the isochromosome in the parent arose mitotically out of a zygote with biparental inheritance of these chromosomes. So, besides the necessity for trisomy rescue or a gamete complementation mechanism in the child, only two generation families should be possible. For de novo isodisomic cases, a monosomy rescue mechanism by centromeric misdivision subsequent to fertilisation of a monosomic gamete by a gamete nullisomic for this chromosome or a trisomic zygote followed by a trisomy rescue and a centromeric misdivision are possible. The first seems to be more likely besides others due to the lack of cases with trisomy mosaicism. Interestingly, in contrast to the general finding of a 2:1 proportion for maternal hetero- and isodisomy, ${ }^{154}$ the majority of non-homologous Robertsonian translocations associated with maternal UPD of one of the chromosomes involved displays heterodisomy (22:3). However, excluding the inherited cases, which must be heterodisomic, the proportion is adequate to the general result. Up to now, seven out of 10 de novo Robertsonian translocations have been found to be heterodisomic.
In early - and therefore unbiased by a clinical phenotypeperformed prenatal diagnoses of 13/14 translocations, only one case with maternal UPD 13 was reported. ${ }^{16}$ What could be the reasons? Because trisomy 13 is viable, while non-mosaic trisomy 14 has never been reported in the literature, the selection for free trisomy 13-particularly in the first weeks-should not be stronger than for free trisomy 14. In addition, there are no arguments that non-disjunction of chromosome 14 is more frequent than non-disjunction of chromosome 13 . Therefore, postzygotic formation of the 13/14 translocation and loss of the paternal chromosome 14 is less likely than meiotic (or premeiotic) formation of the 13/14 translocation and associated chromosome 14 non-disjunction in meiosis followed by trisomy rescue. Maybe there is a mechanism making a 13/14 translocation more vulnerable to chromosome 14 than chromosome 13 non-disjunction.

UPD associated with an SMC is formed either by: (a) functional trisomy rescue by mitotic reduction of the single homologue in a zygote carrying a normal homologue from one parent and a normal homologue and a SMC from the other parent; or (b) postzygotic reduplication of the normal homologue by fertilisation of a normal gamete by a gamete carrying the SMC; or (c) post-fertilisation errors by either mitotic nondysjunction followed by reduction of the single homologue or vice versa; or (d) complementation by fertilisation of a disomic gamete by a gamete carrying the SMC. ${ }^{2}$ So, the most likely mechanism of formation is a postzygotic event. This assumption is supported by the observed expiration of: (a) trisomy due to meiotic non-disjunction; (b) marker formation out of the single parental chromosome; and (c) loss of the marker resulting in UPD, as in a case reported by Bartels et al. ${ }^{153}$

As depicted in table 4, the number of cases with SMC(15) in association with uniparental disomy has increased. Apart from UPD the clinical consequences will depend on the parental origin and the size of the marker chromosome. The phenotype of large SMCs(15) associated with biparentally inherited chromosomes 15 is characterised by muscular hypotonia, developmental delay, seizures, and autism. ${ }^{177}$ Almost all inv dup(15) associated with biparental inherited chromosomes 15 are maternally derived. ${ }^{178}$ The few cases investigated by family studies or somatic cell hybrids demonstrate inter- and intrachromosomal formation. As parental origin of the UPD and the marker from the same parent would require a very complex mechanism of formation, the parental origin of most SMC(15) will be opposite to the parental origin of the UPD. Only two cases displayed maternal uniparental heterodisomy 15 and an associated symmetric inv dup(15) including the PWS/AS region of paternal origin. ${ }^{144} 149$ The first case displayed normal measurements at birth, developmental delay, and minor facial dysmorphisms resembling PWS, but no muscular hypotonia. ${ }^{144}$ The authors speculate about partial rescue of the PWS phenotype. However, mosaicism was of low level $(20 \%)$ and only determined in lymphocytes. For the second case no clinical details are given, but mosaicism was low as well. ${ }^{149}$ A clinical rescue mechanism is also unlikely because gene dosage and expression should be increased and in healthy people there is no hint towards reciprocal neutralisation of maternally and paternally imprinted genes on $15 q 12$. The number of cases with inv dup(15) and UPD 15 looks high, but keeping in mind that more than $50 \%$ of all SMCs derive from chromosome 15, the ratio seems to be similar to the frequency of UPD in other SMCs. Interestingly, to the best of my knowledge, there is no case with UPD and an inherited SMC, neither an SMC(15) nor any other SMC. 
Figure 2 Major mechanisms of formation of genome wide uniparental disomy (UPD) mosaicism: (A) fertilisation of an egg by one sperm, and irregular reduplication and division of the male pronucleus followed by cell division and diploidisation of the male haploid genome resulting in a cell line with a normal biparentally inherited karyotype and a genome wide uniparental cell line; $(B)$ fertilisation of an egg by two sperms followed by cell division and diploidisation of the haploid male genome; or (C) fertilisation of an empty egg and subsequent diploidisation of the male haplotype as well as of a normal egg with a haploid chromosomal complement by a normal sperm followed by amalgamation of both.
A

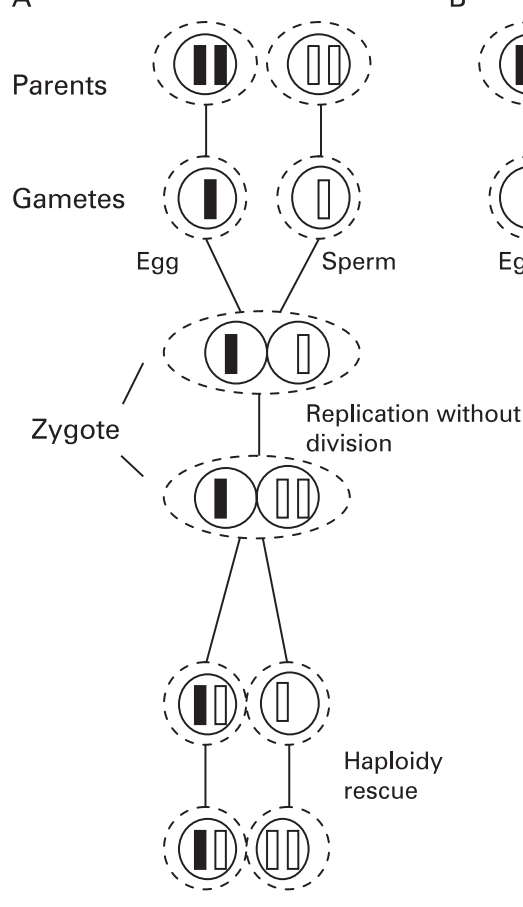

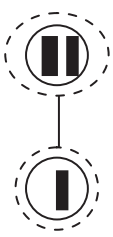

Egg
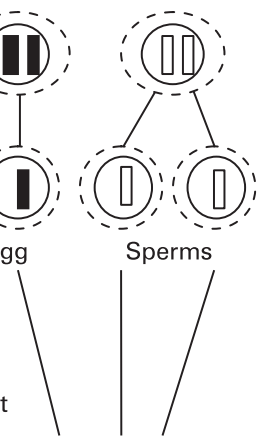

Sperms
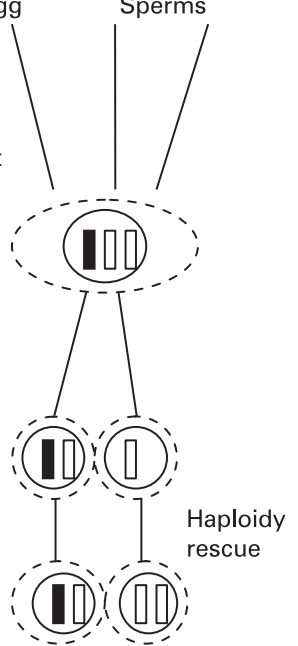

C<smiles>c1ccc(-c2ccccc2)cc1</smiles><smiles>Oc1ccccc1-c1ccccc1-c1ccccc1</smiles>

Egg
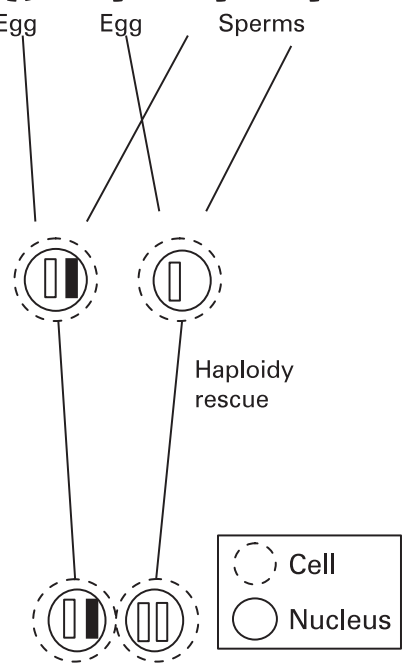

Genome wide UPD associated with a biparentally inherited karyotype in living newborns is a rare finding. It should not be confounded with chimerism, which describes the postzygotic fusion of two regularly fertilised normal eggs. In contrast, genome wide UPD associated with a biparentally inherited karyotype is considered to be formed mainly by three mechanisms (fig 2): (a) fertilisation of an egg by one sperm followed by endoreduplication of the haploid genome of the sperm, division in a biparental diploid cell, and a paternal haploid cell, and somatic reduplication of the paternal genome in the latter; (b) fertilisation of an egg by two sperms followed by a division in a dizygotic daughter cell with a biparental genome and a daughter cell with a haploid paternal genome and again mitotic reduplication in the latter; or (c) regular fertilisation of both an empty egg as well as a normal egg by each one sperm followed by diploidisation of the chromosomal complement of the cell with the haploid paternal genome and amalgamation of both cell populations (fig 2). Such rescue mechanisms following one after another appear to be more likely than the co-occurrence of independent events by chance as, for example, the mechanism leading to a 47,XXY zygote followed by an independent loss of an $\mathrm{X}$ and an $\mathrm{Y}$ chromosome. ${ }^{179}$ As YY cells are not viable in mechanism 1 only female newborns are possible. Vice versa, to result in a newborn male in the second and the third mechanism only one of the two sperms may carry an X chromosome and exact this sperm must become reduplicated. So, the rarity of boys with genome wide UPD associated with a biparentally inherited karyotype is explained. The phenotype of cases with genome wide paternal UPD associated with a biparentally inherited karyotype is variable but in most cases resembles BWS. This is not surprising, as paternal UPD11p15 in BWS is also mosaic in most cases. So, in contrast to most other imprinting disorders, a reduced level of gene expression for paternal UPD11p15 only seems to be sufficient for inducing a clinical phenotype. Similarly, the two cases with genome wide maternal UPD mosaicism have no features of maternal UPD 7 or $15 .^{169} 170$
According to the recommendations of the American Society of Human Genetics, for chromosomes not carrying imprinted genes, generally a minimum of two informative markers per chromosome are accepted for diagnosis of both hetero- and isodisomy. ${ }^{180}$ The same should be demanded as a minimum for the diagnosis of segmental or complex UPD. Results of single nucleotide polymorphism (SNP) microarrays should be controlled by classical microsatellite marker investigation-the latter particularly in the light of recent findings of long stretches of homozygosity in cases with normal biparental inheritance, of the high number of copy number variations in the human genome, and of microsatellite marker mutations and/or null mutations. Now knowing this, some UPD cases reported without investigation of both parents may be questioned.

\section{CONCLUSION}

UPD remains a fascinating peculiarity of chromosomal segregation in humans. The number of reported cases has considerably increased lately and will further increase, but the knowledge about the reasons and the molecular details of basic mechanisms is still very small. Answers will come from investigation of as many cases with complex chromosomal rearrangements as possible for the mechanisms and time of formation and the presence of UPD. Recurrence risk seems to be so low that invasive prenatal diagnosis is normally not indicated. Furthermore, UPD is an other example of the plasticity of the human genome, which for most chromosomes can tolerate the lack of biparental inheritance. In contrast, a minority of genes expressed irregularly as a result of UPD will lead to severely harmful phenotypes.

Acknowledgements: I thank Thomas Bettecken, Max-Planck Institute of Psychiatry, Munich, Germany, for editorial help.

Competing interests: None declared.

Dedicated to Professor Albert Schinzel, Institute of Medical Genetics, University of Zürich, Switzerland, on the occasion of his emeritation. 


\section{REFERENCES}

1. Kotzot D. Complex and segmental uniparental disomy (UPD) - review and lessons from rare chromosomal complements. J Med Genet 2001;38:497-507.

2. Kotzot D. Supernumerary marker chromosomes (SMC) and uniparental disomy (UPD) - coincidence or consequence? J Med Genet 2002;39:775-8.

3. Stratakis C, Taymans SE, Schteingart D, Haddad BR. Segmental uniparental isodisomy (UPD) for 2p16 without clinical symptoms: implications for UPD and other genetic studies of chromosome 2. J Med Genet 2001;38:106-9.

4. Collier DA, Barrett T, Curtis D, Macleod A, Bundey S. DIDMOAD syndrome: confirmation of linkage to chromosome $4 p$, evidence for locus heterogeneity and a patient with uniparental isodisomy for chromosome 4p. Am J Hum Genet 1995;57(Suppl):1084.

5. Yang XP, Inazu A, Yagi K, Kajinami K, Koizumi J, Mabuchi H. Abetalipoproteinemia caused by maternal isodisomy of chromosome $4 q$ containing an intron 9 splice acceptor mutation in the microsomal triglyceride transfer protein gene. Arterioscler Thromb Vasc Biol 1999:19:1950-5.

6. Lopez-Gutierrez AU, Riba L, Ordonez-Sanchez ML, Ramirez-Jimenez, CerrilloHinojosa M, Tusie-Luna MT. Uniparental disomy for chromosome 6 results in steroid 21-hydroxylase deficiency: evidence of different genetic mechanisms involved in the production of the disease. J Med Genet 1998;35:1014-9.

7. Das S, Lese CM, Song M, Jensen JL, Wells LA, Barnoski BL, Roseberry A, Camacho JM, Ledbetter DH, Schnur RE. Partial paternal uniparental disomy of chromosome 6 in an infant with neonatal diabetes, macroglossia, and craniofacial abnormalities. Am J Hum Genet 2000;67:1586-91.

8. Hannula K, Lipsanen-Nyman M, Kontiokari T, Kere J. A narrow segment of maternal uniparental disomy of chromosome 7q31-qter in Silver-Russell syndrome delimits a candidate gene region. Am J Hum Genet 2001;68:247-53.

9. Martin RA, Sabol DW, Rogan PK. Maternal uniparental disomy of chromosome 14 confined to an interstitial segment (14q23-14q24.2). J Med Genet 1999;36:633-6.

10. Eggermann T, Mergenthaler S, Eggermann K, Albers A, Fusch C, Ranke MB, Wollmann HA. Identification of interstitial maternal uniparental disomy (UPD) (14) and complete maternal upd (20) in a cohort of growth-retarded patients. J Med Genet 2001;38:86-9

11. Avivi L, Korenstein A, Braier-Goldstein O, Goldman B, Ravia Y. Uniparental disomy of sex chromosomes in man. Am J Hum Genet 1992;51(Suppl):33.

12. Tompson SW, Ruiz-Perez VL, Wright MJ, Goodship JA. Ellis-van Crefeld syndrome resulting from segmental uniparental disomy of chromosome 4. J Med Genet 2001;38:E18.

13. Rio M, Molinari F, Heuertz S, Ozilou C, Gosset P, Raoul O, Cormier-Daire V, Amiel J, Lyonnet S, Le Merrer M, Turleau C, de Blois MC, Prieur M, Romana S, Vekemans M, Munnich A, Colleaux L. Automated fluorescent genotyping detects $10 \%$ of cryptic subtelomeric rearrangements in idiopathic syndromic mental retardation. J Med Genet 2002;39:266-70.

14. Bastepe $\mathbf{M}$, Lane $\mathbf{A H}$, Jüppner $H$. Paternal uniparental isodisomy of chromosome $20 q$-and the resulting changes in GNAS1 methylation-as a plausible cause of pseudohypoparathyroidism. Am J Hum Genet 2001;68:1283-9.

15. Dupont JM, Cuisset L, Le Tessier D, Vasseur C, Récan D, Cartigny M, Despert F, Bougnère $P$, Jeanpierre $M$, Rabineau $D$. Cytogenetic and molecular studies in 32 Silver Russell syndrome patients (SRS). Eur J Hum Genet 1998;6(Suppl 1):P2.113.

16. Berend SA, Horwitz J, McCaskill Ch, Shaffer LG. Identification of uniparental disomy following prenatal detection of robertsonian translocations and isochromosomes. Am J Hum Genet 2000;66:1787-93.

17. Antonarakis SE, Blouin J-L, Maher J, Avramopoulos D, Thomas G, Talbot CC. Maternal uniparental disomy for human chromosome 14, due to a loss of a chromosome 14 from somatic cells with $\mathrm{t}(13 / 14)$ trisomy 14. Am J Hum Genet 1993;52:1145-52.

18. Barton DE, McQuaid S, Stallings R, Griffin E, Geraghty M. Further evidence for an emerging maternal uniparental disomy chromosome 14 syndrome: analysis of a phenotypically abnormal de novo Robertsonian translocation $t(13 ; 14)$ carrier. Am J Hum Genet 1996;59(Suppl):687

19. Coviello DA, Panucci E, Mantero MM, Perfumo C, Guelfi M, Borronco C, DagnaBricarelli F. Maternal uniparental disomy for chromosome 14. Acta Genet Med Gemellol 1996:45:169-72.

20. Healey S, Powell F, Battersby M, Chenevix-Trench G, McGill J. Distinct phenotype in maternal uniparental disomy of chromosome 14. Am J Med Genet 1994;51:147-9.

21. Papenhausen PR, OT Müller, VP Johnson, M Sutcliffe, ThM Diamond, Kousseff BG. Uniparental isodisomy of chromosome 14 in two cases: an abnormal child and a normal adult. Am J Med Genet 1995;59:271-5.

22. Harrison KJ, Allingham-Hawkins DJ, Hummel J, Meschino WS, Cox DW, Costa TM, Mak-Tam E, Teshina IF, Kamel-Reid S, Winsor EJT. Risk of uniparental disomy in Robertsonian translocation carriers: identification of UPD14 in a small cohort. Am J Hum Genet 1998;63(Suppl):51.

23. Link L, McMilin K, Popovich B, Magenis RE. Maternal uniparental disomy for chromosome 14. Am J Hum Genet 1996;59(Suppl):687.

24. Desilets VA, Yong SL, Kalousek DK, Pantzar TJ, Kwong LC, Siemens C, Langlois S. Maternal uniparental disomy for chromosome 14. Am J Hum Genet 1997;61(Suppl):691.

25. Temple IK, Cockwell A, Hassold T, Pettay D, Jacobs P. Maternal uniparental disomy for chromosome 14. J Med Genet 1991;28:511-4.

26. Cotter PD, Kaffe S, Curdy LD, Jhaveri M, Willner JP, Hirschhorn K. Paternal uniparental disomy for chromosome 14: a case report and review. Am J Med Genet 1997:70:74-9.
27. Wang J-C, Passage MB, Yen PH, Shapiro LJ, Mohandas TK. Uniparental heterodisomy for chromosome 14 in a phenotypically abnormal familial balanced 13/ 14 Robertsonian translocation carrier. Am J Hum Genet 1991;48:1069-74.

28. Berend SA, Feldman GL, McGaskill Ch, Czarnecki P, Van Dyke DL, Shaffer LG. Investigation of two cases of paternal disomy 13 suggests timing of isochromosome formation and mechanisms leading to uniparental disomy. Am J Med Genet 1999;87:278-80.

29. Park JP, Moeschler JB, Hani VH, Hawk AB, Belloni DR, Noll WW, Mohandas TK. Maternal disomy and Prader-Willi syndrome consistent with gamete complementation in a case of a familial translocation (3;15)(p25;q11.2). Am J Med Genet 1998;78:134-9.

30. Smeets DFCM, Hamel BCJ, Nelen MR, Smeets HJM, Bollen JHM, Smits APT, Ropers $\mathrm{H}-\mathrm{H}$, van Oost BA. Prader-Willi syndrome and Angelman syndrome in cousins from a family with a translocation between chromosomes 6 and 15. N Engl J Med 1992;326:807-11

31. Smith A, Deng Z-M, Beran R, Woodage T, Trent RJ. Familial unbalanced translocation $\mathrm{t}(8 ; 15)(\mathrm{p} 23.3 ; \mathrm{q} 11)$ with uniparental disomy in Angelman syndrome. Hum Genet 1994;93:471-3.

32. Nicholls RD, Knoll JHM, Butler MG, Karam S, Lalande M. Genetic imprinting suggested by maternal heterodisomy in non-deletion Prader-Willi syndrome. Nature 1989;342:281-5

33. Smith A, Robson I, Neumann A, Mulcahy M, Chabros V, Deng Z-M, Woodage T, Trent RJ. Fluorescence in-situ hybridisation and molecular studies used in the characterisation of a Robertsonian translocation $(13 q 15 q)$ in Prader-Willi syndrome. Clin Genet 1993;43:5-8.

34. Toth-Fejel SE, Olson S, Gunter K, Quan F, Wolford J, Popovich BW, Magenis RE. The impact of imprinting: Prader-Willi syndrome resulting from chromosome translocation, recombination, and nondisjunction. Am J Hum Genet 1996;58:1008-16.

35. Woodage T, Deng Z-M, Prasad M, Smart R, Lindeman R, Christian SL, Ledbetter $\mathrm{DL}$, Robson L, Smith A, Trent RJ. A variety of genetic mechanisms are associated with the Prader-Willi syndrome. Am J Med Genet 1994;54:219-26.

36. Wang J-C, Mamunes P, Kou S-Y, Schmidt J, Mao R, Hsu WT. Centromeric DNA break in a 10;16 reciprocal translocation associated with trisomy 16 confined placental mosaicism and maternal uniparental disomy for chromosome 16. Am J Med Genet 1998:80:418-22.

37. Chen P, Young R, Mu X, Nandi K, Miao S, Prouty L, Ursin S, Gonzalez J, Yanamandra K. Uniparental isodisomy resulting from $46, X X, \mathrm{i}(1 \mathrm{p}), \mathrm{i}(1 \mathrm{q})$ in a woman with short stature ptosis, micro/retrognathia, myopathy, deafness, and sterility. Am J Med Genet 1999;82:215-8.

38. Albrecht B, Mergenthaler S, Eggermann K, Zerres K, Passarge E, Eggermann T. Uniparental isodisomy for paternal $2 p$ and maternal $2 q$ in a phenotypically normal female with two isochromosomes, i(2p) and i(2q). J Med Genet 2001;38:214-5.

39. Bernasconi F, Karagüzel A, Celep F, Keser I, Lüleci G, Dutly F, Schinzel A. Norma phenotype with maternal isodisomy in a female with two isochromosomes: i(2p) and $\mathrm{i}(2 \mathrm{q})$. Am J Hum Genet 1996;59:1114-8.

40. Shaffer LG, McCaskill Ch, Egli CA, Baker JC, Johnston KM. Is there an abnormal phenotype associated with maternal isodisomy for chromosome 2 in the presence of two isochromosomes? Am J Hum Genet 1997;61:462-3.

41. Lindenbaum RH, Woods CG, Norbury CG, Povey S, Rystecki G. An individual with maternal disomy of chromosome 4 and iso (4p), iso (4q). Am J Hum Genet 1991;49(Suppl):1582.

42. Eggerding FA, Schonberg SA, Chehab FF, Norton ME, Cox VA, Epstein ChJ. Uniparental isodisomy for paternal $7 p$ and maternal $7 q$ in a child with growth retardation. Am J Hum Genet 1994;55:253-65.

43. Kotzot D, Thamm B, Holland H, Keller E, Froster U. Maternal isochromosome 7q and paternal isochromosome $7 p$ in a boy with growth retardation. Am J Med Genet 2001;102:169-72.

44. Piantanida M, Dellavecchia C, Floridia G, Giglio S, Hoeller H, Dordi B, Danesino C, Schinzel A, Zuffardi 0. Ataxic gait and mental retardation with absence of the paternal chromosome 8 and an idic(8)(p23.3): imprinting effect or nullisomy for distal 8p genes? Hum Genet 1997;99:766-71.

45. Björck EJ, Anderlid B-M, Blennow E. Maternal isodisomy of chromosome 9 with no impact on the phenotype in a woman with two isochromosomes: i(9p) and i(9q). Am J Med Genet 1999;87:49-52.

46. Slater H, Shaw JH, Bankier A, Forrest SM. UPD 13: no indication of maternal or paternal imprinting of genes on chromosome 13. J Med Genet 1995;33:493.

47. Slater H, Shaw JH, Dawson G, Bankier A, Forrest SM. Maternal uniparental disomy of chromosome 13 in a phenotypically normal child. J Med Genet 1994;31:644-6.

48. Stallard R, Krueger S, James RS, Schwartz S. Uniparental isodisomy 13 in a normal female due to transmission of a maternal t(13q13q). Am J Med Genet 1995;57:14-18.

49. Berends MJ, Hordijk R, Oosterwijk JC, Halley DJ, Sorgedrager N. Two cases of maternal uniparental disomy 14 with a phenotype overlapping with the Prader-Willi phenotype. Am J Med Genet 1999;84:76-9.

50. Järvelä I, Savukoski M, Ämmälä P, von Koskull H. Prenatally detected paternal uniparental chromosome 13 isodisomy. Prenat Diagn 1998;18:1169-73.

51. Soler A, Margarit E, Queralt R, Carrio A, Costa D, Gomez D, Ballesta F. Paternal isodisomy 13 in a normal newborn infant after trisomy rescue evidenced by prenatal diagnosis. Am J Med Genet 2000;90:291-3.

52. Papenhausen PR, Tepperberg JH, Mowrey PN, Gadi IK, Shah HO, Sherman J, Pulijaal V, Nitowsky H, Sachs G, Lin JH. UPD risk assessment: three cytogenetic subgroups. Am J Hum Genet 1999;65(Suppl):1996. 
53. Robinson WP, Bernasconi F, Basaran S, Yüksel-Apak M, Neri G, Serville F, Balicek P, Haluza R, Farah LMS, Lüleci G, Schinzel A. A somatic origin of homologous Robertsonian translocations and isochromosomes. Am J Hum Genet 1994;54:290-302.

54. Manzoni M, Pramparo T, Stroppolo A, Chiaino F, Bosi E, Zuffardi 0, Carrozzo R. A patient with maternal chromosome 14 UPD presenting with a mild phenotype and MODY. Clin Genet 2000:57:5:406-8.

55. Miyoshi 0, Hayashi S, Fujimoto M, Tomita H, Sohda M, Niikawa N. Maternal uniparental disomy for chromosome 14 in a boy with intrauterine growth retardation. $J$ Hum Genet 1998:43:138-42.

56. Pentao L, Lewis RA, Ledbetter DH, Patel PI, Lupski JR. Maternal uniparental isodisomy of chromosome 14: association with autosomal recessive rod monochromacy. Am J Hum Genet 1992:50:690-9.

57. Splitt MP, Goodship JA. Another case of maternal uniparental disomy chromosome 14 syndrome. Am J Med Genet 1997:72:239-40.

58. Tomkins DJ, Roux AF, Waye J, Freeman VC, Cox DW, Whelan DT. Maternal uniparental isodisomy of chromosome 14 associated with a paternal $t(13 q 14 q)$ and precocious puberty. Eur J Hum Genet 1996:4:153-9.

59. Walter CA, Shaffer LG, Kaye Cl, Huff RW, Ghidoni PD, McCaskill Ch, McFarland MB, Moore ChM. Short-limb dwarfism and hypertrophic cardiomyopathy in a patient with paternal isodisomy 14: 45,XY,idic(14)(p11). Am J Med Genet 1996;65:259-65.

60. Bettio D, Giardino D, Rizzi N, Riva P, Volpi L, Barantani E, Tagliferri A, Larizza L. Isochromosome $15 q$ of maternal origin in a Prader-Willi patient with pituitary adenoma. Acta Genet Med Gemellol 1996;45:213-6.

61. Freund M, Dahan K, Liebaers I, Hubimont C, Verellen-Dumoulin Ch. Prenata diagnosis of the Prade-Willi syndrome throught a 15;15 isochromosome and maternal isodisomy. Eur J Hum Genet 2000:8(Suppl 1):P109.

62. Hamabe J, Fukushima Y, Harada N, Abe K, Matsuo N, Nagai T, Yoshioka A, Tonoki H, Tsukino R, Niikawa N. Molecular study of Prader-Willi syndrome: deletion, RFLP, and phenotype analysis of 50 patients. Am J Med Genet 1991:41:54-63.

63. Saitoh S, Mutirangura A, Kuwano A, Ledbetter DH, Niikawa N. Isochromosome 15q of maternal origin in two Prader-Willi syndrome patients previously diagnosed errorneously as cytogenetic deletions. Am J Med Genet 1994;50:64-7.

64. Freeman SB, May KM, Pettay D, Fernhoff PM, Hassold TJ. Paternal uniparental disomy in a child with a balanced 15;15 translocation and Angelman syndrome. Am J Med Genet 1993;45:625-30.

65. Fridman C, Varela MC, Nicholls RD, Koiffmann CP. Unusual clinical features in an Angelman syndrome patient with uniparental disomy due to a translocation 15q15q. Clin Genet 1998;54:303-8

66. Guitart M, Escudero T, Gabau E, Dominguez MC, Jimenez MD, Mila M, Coll MD. Two new cases of Angelman syndrome with a balanced 15;15 translocation and paternal uniparental disomy. Cytogenet Cell Genet 1997;77(Suppl):P227.

67. Ramsden S, Gaunt L, Seres-Santamaria A, Clayton-Smith J. A case of Angelman syndrome arising as a result of a de novo Robertsonian translocation. Acta Genet Med Gemellol 1996;45:255-61.

68. Tonk V, Schultz RA, Christian SL, Kubota T, Ledbetter DH, Wilson GN. Robertsonian $(15 q ; 15 q)$ translocation in a child with Angelman syndrome: evidence of uniparental disomy. Am J Med Genet 1996:66:426-8.

69. Mignon C, Malzac P, Moncla A, Depetris D, Roeckel N, Croquette MF, Mattei MG. Clinical heterogeneity in 16 patients with inv dup 15 chromosome: cytogenetic and molecular studies, search for an imprinting effect. Eur J Hum Genet 1996;4:88-100.

70. Créau-Goldberg N, Gegonne A, Delabar J, Cochet C, Cabanis M-0, Stehlin D, Turleau C, de Grouchy J. Maternal origin of a de novo balanced t(21q;21q) identified by ets-2 polymorphism. Hum Genet 1987;76:396-8.

71. Rogan PK, Sabol DW, Punnett HH. Maternal uniparental disomy of chromosome 21 in a normal child. Am J Med Genet 1999:83:69-71.

72. Blouin JL, Avramopoulos D, Pangalos C, Antonarakis SE. Normal phenotype with paternal uniparental isodisomy for chromosome 21. Am J Hum Genet 1993;53:1074-8.

73. Miny P, Koppers B, Bogadanova N, Schulte-Vallentin M, Horst J, Dworniczak B. Paternal uniparental disomy 22. Med Genetik 1995;7:216-H76.

74. Kirkels VGHJ, Hustin Th WJ, Scheres JMJC. Habitual abortion and translocation (22q;22q): unexpected transmission from a mother to her phenotypically normal daughter. Clin Genet 1980;18:456-61.

75. Palmer CG, Schwartz S, Hodes ME. Transmission of a balanced homologous $\mathrm{t}(22 \mathrm{q} ; 22 q)$ translocation from mother to normal daughter. Clin Genet 1980:17:418-22.

76. Schinzel A, Basaran S, Bernasconi F, Karaman B, Yüksel Apak M, Robinson WP Maternal uniparental disomy 22 has no impact on the phenotype. Am J Hum Genet 1993:54:21-4.

77. Temple IK, James RS, Crolla JA, Sitch FL, Jacobs PA Howell WM, Betts P. An imprinted gene(s) for diabetes? Nature Genet 1994:9:110-2.

78. Miyoshi 0, Kondoh T, Taneda H, Otsuka K, Matsumoto T, Niikawa N 47,XX,UPD(7)mat, +r(7)pat/46,XX,UPD(7)mat mosaicism in a girl with Silver-Russell syndrome (SRS): possible exclusion of the putative SRS gene from a 7p13-q11 region. J Med Genet 1999;36:326-9.

79. Turleau C, Viot G, Burglen L, Caillez D, Layet V, Chauveau P, Faivre L, Morichon N, Delezoide A-L, Prieur M, Munnich A, Vekemans M. Uniparental disomy of chromosome 8 due to a pseudodicentric chromosome: possible mechanisms and consequences. Am J Hum Genet 1998:63(Suppl):865.

80. Bettio D, Rizzi N, Giardino D, Gurrieri F, Silvestri G, Grugni G, Larizza L. FISH characterization of small superumerary marker chromosomes in two Prader-Willi patients. Am J Med Genet 1997:68:99-104.
81. Cheng SD, Spinner, NB, Zackai EH, Knoll JH. Cytogenetic and molecular characterization of inverted duplicated chromosomes 15 from 11 patients. Am J Hum Genet 1994;55:753-9.

82. Christian SL, Mills P, Das S, Ledbetter DH. High risk of uniparental disomy 15 associated with amniotic fluid containing de novo small supernumerary marker 15 chromosomes. Am J Hum Genet 1998;63:A11.

83. Ebrahim SAD, Feldman B, Knaus A, Gyi K, Mills PL, Johnson MP, Evans Ml. Prenatal diagnosis of maternal uniparental disomy of chromosome 15 in association with de novo supernumerary marker chromosome 15. Am J Hum Genet 1998:63(Suppl):A162

84. Robinson WP, Wagstaff J, Bernasconi F, Baccichetti C, Artifoni L, Franzoni E, Suslak L, Shih LY, Aviv H, Schinzel AA. Uniparental disomy explains the occurrence of the Angelman or Prader-Willi syndrome in patients with an additional small inv dup(15) chromosome. J Med Genet 1993;30:756-60.

85. Lebbar A, Dupont JM, Cuisset L, Pinton F, Vasseur C, Le Tessier D, Denavit MF Ponsot G, Delpech M, Rabineau D. Clinical features of Prader-Willi syndrome in a girl with methylation status of Angelman syndrome. Eur J Hum Genet 1998:6(Suppl):97A

86. Schinzel A, Kotzot D, Brecevic L, Robinson WP, Dutly F, Dauwerse H, Binkert F, Ausserer B. Trisomy first, translocation second, uniparental disomy and partial trisomy third: a new mechanism for complex chromosomal aneuploidy. Eur J Hum Genet 1997:5:308-14.

87. Spinner NB, Rand E, Bucan M, Jirik E, Gogolin-Ewens C, Riethman HC, Mc Donald-Mc Ginn DM, Zackai EH. Paternal uniparental isodisomy for human chromosome 20 and absence of external ears. Am J Hum Genet 1994:55(Suppl):674.

88. Chudoba I, Franke Y, Senger G, Sauerbrei G, Demuth S, Beensen V, Neumann A Hansmann I, Claussen U. Maternal UPD 20 in a hyperactive child with severe growth retardation. Eur J Hum Genet 1999:7:533-40.

89. Dawson AJ, Mears AJ, Chudley AE, Bech-Hansen T, McDermid H. Der(22)t(11;22) resulting from paternal de novo translocation, adjacent 1 segregation, and materna heterodisomy of chromosome 22. J Med Genet 1996;33:952-6.

90. Migeon BR, Jeppesen P, Torchia BS, Fu S, Dunn MA, Axelman J, Schmeckpeper BJ, Fantes J, Zori RT, Driscoll DJ. Lack of $X$ inactivation associated with maternal $X$ isodisomy: evidence for a counting mechanism prior to $X$ inactivation during human embryogenesis. Am J Hum Genet 1996;58:161-70.

91. Yorifuji T, Muroi J, Kawai M, Uematsu A, Sasaki H, Momoi T, Kaji M, Yamanaka Ch, Furusho K. Uniparental and functional X disomy in Turner syndrome patients with unexplained mental retardation and $\mathrm{X}$ derived marker chromosomes. J Med Genet 1998;35:539-44.

92. Turner C, Dennis NR, Skuse DH, Jacobs PA. Seven ring $(X)$ chromosomes lacking the XIST locus, six with an unexpectedly mild phenotype. Hum Genet 2000:106:93-100.

93. Weil D, Portnoi M-F, Levilliers J, Wang I, Mathieu M, Taillemite J-L, Meier M, Boudailliez B, Petit Ch. A 45,X male with an $X ; Y$ translocation: implications for the mapping of the genes responsible for Turner syndrome and $X$-linked chondrodysplasia punctata. Hum Mol Genet 1993;2:1853-6.

94. Engel E. A new genetic concept: uniparental disomy and its potential effect, isodisomy. Am J Med Genet 1980;6:137-43.

95. Henry I, Puech A, Riesewijk A, Ahnine L, Mannens M, Beldjord C, Bitoun P. Tournade MF, Landrieu P, Junien C. Somatic mosaicism for partial paternal isodisomy in Wiedemann-Beckwith syndrome: a post-fertilization event. Eur J Hum Genet 1993;1:19-29

96. Perrault I, Hanein S, Delphin N, Gerber S, Dufier JL, Kaplan J, Rozet JM. Uncommon rearrangements and de novo mutations associated with Leber congenital amaurosis. Am J Hum Genet 2006;79:(4 Suppl):1940.

97. Riveiro-Alvarez R, Valverde D, Lorda-Sanchez I, Trujillo-Tiebas MJ, Cantalapiedra D, Vallespin E, Aguirre-Lamban J, Ramos C, Ayuso C. Partial paternal uniparental disomy (UPD) of chromosome 1 in a patient with Stargardt disease. Mol Vis 2007;13:96-101.

98. Eriksson M, Brown WT, Gordon LB, Glynn MW, Singer J, Scott L, Erdos MR, Robbins ChM, Moses TY, Berglund P, Dutra A, Pak E, Durkin S, Csoka AB, Boehnke M, Glover TW, Collins FS. Recurrent de novo point-mutations in lamin A cause Hutchinson-Gilford progeria syndrome. Nature 2003;423:293-8.

99. Bakker B, Bikker H, Hennekam RC, Lommen EJ, Schipper MG, Vulsma T, de Vijlde $\mathrm{JJ}$. Maternal isodisomy for chromosome $2 p$ causing severe congenital hypothyroidism. J Clin Endocrinol Metab 2001;86:1164-8.

100. Chevalier-Porst F, Rolland MO, Cochat P, Bozon D. Maternal isodisomy of the telomeric end of chromosome 2 is responsible for a case of primary hyperoxaluria type 1. Am J Med Genet A 2004:132A:80-3.

101. Schollen E, Grünewald S, Keldermans L, Albrecht B, Körner C, Matthjis G. CDG-Id caused by homozygosity for an ALG3 mutation due to segmental maternal isodisomy UPD3(q21.3-qter). Eur J Med Genet 2005:48:153-8.

102. Lin SP, Huang SY, Tu ME, Wu YH, Lin CY, Lin HY, Lee-Chen GJ. Netherton syndrome: mutation analysis of two Taiwanese families. Arch Dermatol Res 2007:299:145-50

103. Seal JL, Gornick MC, Gogtay N, Shaw P, Greenstein DK, Coffey M, Gochman PA Stromberg T, Chen Z, Merriman B, Nelson SF, Brooks J, Arepalli S, Wavrant-De Vrieze F, Hardy J, Rapoport JL, Addington AM. Segmental uniparental isodisomy on 5q32-qter in a patient with childhood-onset schizophrenia. J Med Genet 2006:43:887-92.

104. Zühlke C, Spranger M, Spranger S, Voigt R, Lanz M, Gehlken U, Hinrichs F, Schwinger E. SCA17 caused by homozygous repeat expansion in TBP due to partial isodisomy 6. Eur J Hum Genet 2003:11:629-32. 
105. Reboul MP, Tandonnet O, Biteau N, Belet-de Putter C, Rebouissoux L, Moradkhani K, Vu PY, Saura R, Arveiler B, Lacombe D, Taine L, Iron A. Mosaic maternal uniparental isodisomy for chromosome 7q21-qter. Clin Genet 2006;70:207-13.

106. Tsukishiro S, Li OY, Tanemura M, Sugiura-Ogasawara M, Suzumori K, Sonta S. Paternal uniparental disomy of chromosome 14 and unique exchange of chromosome 7 in cases of spontaneous abortion. J Hum Genet 2005;50:112-17.

107. Ravine D, Lazarou LP, Fisher PJ, Doull IJM, Mac Donald M, Thompson PW, Gill H, Meredith AL, Clarke A, Little E. Uniparental disomy, molecular and social difficulties in interpretation. J Med Genet 2001;37(Suppl 1):4-37.

108. Haefele AL, Figlewicz DA, Stodgell CJ. Apparent uniparental disomy in a familial case of autism spectrum disorder. Am J Hum Genet 2002;71(Suppl 4):1553.

109. Haag MM, Beischel LS, McCann CL, Reynolds JF, Phillips SM, Tunby ML, Hansen JC, Johnson JP. Molecular rescue by mitotic recombination as an explanation for recurrence of 11q- Jacobsen syndrome in two brothers. Am J Hum Genet 2001;69(Suppl 4):2382.

110. Towner D, Yang SP, Shaffer LG. Prenatal ultrasound findings in a fetus with paternal uniparental disomy 14q12-qter. Ultrasound Obstet Gynecol 2001;18:268-71.

111. Kagami M, Nishimura G, Okuyama T, Hayashidani M, Takeuchi T, Tanaka S, Ishino F, Kurosawa K, Ogata T. Segmental and full paternal isodisomy for chromosome 14 in three patients: narrowing the critical region and implication for the clinical features. Am J Med Genet 2005;138A:127-32

112. Nazarenko S, Sazhenova E, Baumer A, Schinzel A. Segmental maternal heterodisomy of the proximal part of chromosome 15 in an infant with Prader-Willi syndrome. Eur J Hum Genet 2004;12:411-14.

113. Hussain K, Flanagan SE, Smith W, Ashworth M, Day M, Pierro A, Ellard S. An ABCC8 gene mutation and mosaic uniparental isodisomy resulting in atypical diffuse congenital hyperinsulinism. Diabetes 2008:57:259-63.

114. Coveler KJ, Sutton VR, Knox-DuBois C, Shaffer LG. Comprehensive microsatellite marker analysis contradicts previous report of segmental maternal heterodisomy of chromosome 14. J Med Genet 2003:40:e26.

115. Silverstein S, Lerer I, Sagi M, Frumkin A, Ben-Neriah Z, Abeliovich D. Uniparental disomy in fetuses diagnosed with balanced Robertsonian translocations: risk estimate. Prenat Diagn 2002;22:649-51.

116. Giunti L, Lapi E, Guarducci S, Ricci U, Cecconi A, Andreucci E, Ottaviani M, Uzielli MLG. Maternal heterodisomy for chromosome 14 and 13/14 Robertsonian translocation in a female with normal mental development, short stature and dysmorphic features. Eur J Hum Genet 2002;10(Suppl 1):P0214.

117. Takahashi I, Takahashi T, Utsunomiya M, Takada G, Koizumi A. Long-acting gonadotropin-releasing hormone analogue treatment for central precocious puberty in maternal uniparental disomy chromosome 14. Tohoku J Exp Med 2005:207:333-8.

118. Krabchi K, Ferland M, Halal F, Russel L, Duncan AMV, Drouin R. Unusual clinical features observed in a young girl having an inherited maternal translocation (13;14) with a mixed maternal uniparental hetero and isodisomy 14. Am J Hum Genet 2005;77(Suppl 1):834

119. Rocha MG, Pinto-Basto J, Garcia E, Reis Lima M, Pinto M, Fortuna A. Maternal uniparental disomy of chromosome [mUPD(14)] in a boy with rob(13;14)mat. Eur J Hum Genet 2006;14(Supp 1):P0182, p139.

120. Mitter D, Buiting K, v. Eggeling F, Kuechler A, Liehr Th, Mau-Holzmann UA, Prott E$\mathrm{Ch}$, Wieczorek D, Gillessen-Kaesbach G. Is there a higher incidence of maternal uniparental disomy 14 [upd(14)mat]? Detection of 10 new patients by methylationspecific PCR. Am J Med Genet 2006;140A:2039-49.

121. Worley KA, Rundus VR, Lee EB, Hannig VL, Hedges LK, Tsuchiya K, Phillips JA III. Maternal uniparental disomy 14 presenting as language delay. Am J Hum Genet 2001;69 (Suppl 4):738

122. Yano S, Li L, Owen S, Wu S, Tran T. A further delineation of the paternal uniparental disomy (UPD) 14: the fifth reported liveborn case. Am J Hum Genet 2001;69 (Suppl 4):739.

123. Kurosowa K, Sasaki H, Sato $Y$, Yamanaka M, Shimizu M, Ito Y, Okuyama T, Matsuo M, Imaizumi K, Kuroki Y, Nishimura G. Paternal UPD14 is responsible for a distinctive malformation complex. Am J Med Genet 2002;110:268-72.

124. Berend SA, Bejjani BA, McCaskill C, Shaffer LG. Identification of uniparental disomy in phenotypically abnormal carriers of isochromosomes or Robertsonian translocations. Am J Med Genet 2002;111:362-5.

125. Sensi A, Cavani S, Villa N, Pomponi MG, Fogli A, Gualandi F, Grasso M, Sala E, Pietrobono R, Baldinotti F, Savin E, Ferlini A, Cecconi M, Rossi S, Gallone S, Bellini C, Neri G, Martinoli E, Simi P, Dalpra L, Genuardi M, Dagna-Bricarelli F, Calzolari E. Nonhomologous Robertsonian translocations (NHRTs) and uniparental disomy (UPD) risk: an Italian multicentric prenatal survey. Prenat Diagn 2004;24:647-52.

126. Ruggeri A, Dulcetti F, Miozzo M, Grati FR, Grimi B, Bellato S, Natacci F, Maggi F, Simoni G. Prenatal search for UPD 14 and UPD 15 in 83 cases of familial and de novo heterologous Robertsonian translocations. Prenat Diagn 2004;24:997-1000.

127. Calounova G, Novotna D, Simandlova M, Havlovicova M, Zumrova A, Kocarek E Sedlacek Z. Prader-Willi syndrome due to uniparental disomy in a patient with a balanced chromosomal translocation. Neuroendocrinol Lett 2006;27:579-85.

128. Flori E, Biancalana V, Girard-Lemaire F, Favre R, Flori J, Doray B, Mandel JL. Difficulties of genetic counselling and prenatal disgnosis in a consanguineous couple segregating for the same translocation $(14 ; 15)(q 11 ; q 13)$ and at risk for Prader-Willi and Angelman syndrome. Eur J Hum Genet 2004;12:181-6.

129. Stuke-Sontheimer A, Chaoui R, Unger M, Ramel C, von Eggeling F, Thiel G, Hoeltzenbein M. Fetal left isomerism (polysplenia) and maternal uniparental isodisomy 14: evidence for a recessive gene for heterotaxia on chromosome 14 ? Medgen 2007:18:32-P022.
130. Falk MJ, Curtis CA, Bass NE, Zinn AB, Schwartz S. Maternal uniparental disomy chromosome 14: case report and literature review. Pediatr Neurol 2005;32:116-20.

131. Kayashima T, Katahira M, Harada N, Miwa N, Ohta T, Yoshiura K, Matsumoto N, Nakane Y, Nakamura Y, Kajii T, Niikawa N, Kishino T. Maternal isodisomy for 14q21 q24 in a man with diabetes mellitus. Am J Med Genet 2002;111:38-42.

132. Stevenson DA, Brothman AR, Chen Z, Bayrak-Toydemir P, Longo N. Paternal uniparental disomy of chromosome 14: confirmation of a clinically-recognizable phenotype. Am J Med Genet 2004;139:88-91.

133. McGowan KD, Weiser JJ, Horwitz J, Berend SA, McCaskill Ch, Sutton VR, Shaffer LG. The importance of investigating for uniparental disomy in prenatally identified balanced acrocentric rearrangements. Prenat Diagn 2002;22:141-3.

134. Gutkowska A, Tylki-Szymańska A, Popowska E, Bielińska B, Jurkiewicz D, Krajewska-Walasek M. A case described as translocation 15;15 revised: maternal 15 UPD, resulting from isochromosome 15, in a PWS patient. Eur J Med Genet 2005:48:207-9.

135. Baumer A, Basaran S, Taralczak M, Cefle K, Ozturk S, Palanduz S, Schinzel A. Initial maternal meiotic I error leading to the formation of a maternal $\mathrm{i}(2 \mathrm{q})$ and a paternal $\mathrm{i}(2 \mathrm{p})$ in a healthy male. Cytogenet Genome Res 2007:118:38-41.

136. Röthlisberger B, Zerova T, Kotzot D, Buzhievskaya TI, Balmer D, Schinzel A Supernumerary marker chromosome (1) of paternal origin and maternal uniparental disomy 1 in a developmentally delayed child. J Med Genet 2001;38:885-8.

137. Eggermann T, Krause-Plonka I, Wollmann HA, Zerres K, Dai G, Meyer E, Bartsch 0. Supernumerary marker chromosome 7 and maternal uniparental disomy 7 in a boy with growth retardation and triangular face. Clin Dysmorphol 2006;15:9-12.

138. Combi R, Sala E, Villa N, Crosti F, Beccaria L, Cogliardi A, Tenchini ML, Dalprà L. Maternal heterodisomy/isodisomy and paternal supernumerary ring of chromosome 7 in a child with Silver-Russell syndrome. Clin Dysmorphol 2008;17:35-9.

139. Anderlid B-M, Sahlen S, Schoumans J, Holmberg E, Ahsgren I, Mortier G, Speleman F, Blennow E. Detailed characterization of 12 supernumerary ring chromosomes using micro-FISH and search for uniparental disomy. Am J Med Genet 2001:99:223-33.

140. Von Eggeling F, Hoppe C, Bartz U, Starke H, Houge G, Claussen U, Ernst G, Kotzot $D$, Liehr T. Maternal uniparental disomy 12 in a healthy girl with a 47,XX,+der(12)(:p11->q11:)/46,XX karyotype. J Med Genet 2002:39:519-21.

141. Mattes J, Whitehead B, Liehr T, Wilkinson I, Bear J, Fagan K, Craven P, Bennetts B, Edwards M. Paternal uniparental isodisomy for chromosome 14 with mosaicism for a supernumerary marker chromosome 14. Am J Med Genet 2007;143A:2165-71.

142. Constantinou M, Kałuzewski B, Helszer Z, Zajac E, Nowacka J. Prenatal detection of maternal UPD15 in a new case with i(15p) by timing replication test (TRT) and methylation analysis. J App/ Genet 2003;44:209-18.

143. Wang YM, Chuang L, Wang BT, Kuo PL. Maternal uniparental disomy in a patient with Prader-Willi syndrome with an additional small inv dup(15) chromosome. $J$ Formos Med Assoc 2004;103:943-7.

144. Saitoh S, Hosoki K, Takano K, Tonoki H. Mosaic paternally derived inv dup(15) may partially rescue the Prader-Willi syndrome phenotype with uniparental disomy. Clin Genet 2007:72:378-80.

145. Roberts S, Maggouta F, Thompson R, Price S, Thomas S. A patient with a supernumerary marker chromosome (15), Angelman syndrome, and uniparental disomy resulting from paternal meiosis II non-disjunction. J Med Genet 2002:39:E9.

146. Liehr T, Brude E, Gillessen-Kaesbach G, König R, Mrasek K, von Eggeling F, Starke H. Prader-Willi syndrome with a karyotype $47, X Y,+\min (15)($ pter- $>$ q11.1:) and maternal UPD 15 -case report plus review of similar cases. Eur J Med Genet 2005; 48:175-81

147. Borelina D, Esperante S, Gutnisky V, Ferreiro V, Ferrer M, Giliberto F, Frechtel G, Francipane L, Szijan I. Supernumerary marker 15 chromosome in a patient with Prader-Willi syndrome. Clin Genet 2004;65:242-3.

148. Werner M, Ben-Neriah Z, Silverstein S, Lerer I, Dagan Y, Abeliovich D. A patient with Prader-Willi syndrome and a supernumerary marker chromosome r(15)(q11.1 13p11.1)pat and maternal heterodisomy. Am J Med Genet 2004;129A:176-9.

149. Baumer A, Wiedemann U, Hergersberg M Schinzel A A novel MSP/DHPLC method for the investigation of the methylation status of imprinted genes enables the molecular detection of low cell mosaicisms. Hum Mutat 2001:17:423-30.

150. Ichikawa M, Okajima M, Wada T, Gokan Y, Shimakage H, Tonoki H, Saitoh S. Nonchromosome 15 marker chromosome in a Prader-Willi syndrome patient with uniparental disomy. Pediatr Int 2006;48:97-9.

151. Kron A, Trübenbach J, Liehr Th, Decker J, Steinberger D. Characterization of a prenatally diagnosed de novo small supernumerary marker harbouring material of chromosome 16. Medgen 2007;18:47-P89.

152. Bartsch 0, Loitzsch A, Kozlowski P, Mazauric ML, Hickmann G. Forty-two supernumerary marker chromosomes (SMCs) in 43273 prenatal samples: chromosomal distribution, clinical findings, and UPD studies. Eur J Hum Genet 2005:13:1192-204.

153. Bartels I, Schlueter G, Liehr T, von Eggeling F, Starke H, Glaubitz R, Burfeind P. Supernumerary small marker chromosome (SMC) and uniparental disomy 22 in a child with confined placental mosaicism of trisomy 22: trisomy rescue due to marker chromosome formation. Cytogenet Genome Res 2003;101:103-5

154. Kotzot D, Utermann G. Uniparental disomy (UPD) other than 15: phenotypes and bibliography updated. Am J Med Genet 2005:136A:287-305

155. Venditti CP, Hunt P, Donnenfeld A, Zackai E, Spinner NB. Mosaic paternal uniparental (iso)disomy for chromosome 20 associated with multiple anomalies. Am J Med Genet 2004:124A:274-9. 
156. Starke H, Mitulla B, Nietzel A, Heller A, Beensen V, Grosswendt G, Claussen U, Von Eggeling $F$, Liehr $T$. First patient with trisomy 21 accompanied by an additional $\operatorname{der}(4)(: p 11->q 11:)$ plus partial uniparental disomy 4p15-16. Am J Med Genet 2003:116:26-30.

157. Parker EA, Hovanes K, Germak J, Porter F, Merke DP. Maternal 21-hydroxylase deficiency and uniparental isodisomy of chromosome 6 and $X$ results in a child with 21-hydroxylase deficiency and Klinefelter syndrome. Am J Med Genet 2006;140A:2236-40.

158. Felix TM, Tansey MJ, Patil SR, Murray JC, Dagle JM. Double paternal nondisjunction in an infant with transient neonatal diabetes mellitus and Klinefelter syndrome. Am J Med Genet 2007;143A:895-8.

159. Valerio G, Franzese A, Palmieri A, Mackay DJ, Gardner RJ, Temple IK. Central precocious puberty in a girl with triple $\mathrm{X}$ syndrome and neonatal diabetes mellitus associated with paternal isodisomy of chromosome 6. J Pediatr Endocrinol Metab 2001;14:897-900.

160. Chun-Hui Tsai A, Gibby T, Beischel L, McGavran L, Johnson JP. A child with Angelman syndrome and trisomy 13 findings due to associated paternal UPD 15 and segmental UPD 13. Am J Med Genet 2004;126A:208-12.

161. Bartsch 0, Petersen MB, Stuhlmann I, Mau G, Frantzen M, Schwinger E, Antonarakis SE, Mikkelsen M. Compensatory uniparental disomy of chromosome 21 in two cases. J Med Genet 1994;31:534-40.

162. Wilson M, Peters G, Bennetts B, McGillivray G, Wu ZH, Poon C, Algar E. The clinical phenotype of mosaicism for genome-wide paternal uniparental disomy: two new reports. Am J Med Genet 2008;146:137-48.

163. Hoban PR, Heighway J, White GR, Baker B, Gardner J, Birch JM, Morris-Jones P, Kelsey AM. Genome-wide loss of maternal alleles in a nephrogenic rest and Wilms' tumour from a BWS patient. Hum Genet 1995;95:651-6.

164. Bryke CR, Garber T, Israel J. Evolution of a complex phenotype in a unique patient with a paternal uniparental disomy for every chromosome cell line and a normal biparental inheritance cell line. Am J Hum Genet 2004;75(Suppl):831.

165. Giurgea I, Sanlaville D, Fournet JC, Sempoux C, Bellanné-Chantelot C, Touati G, Hubert L, Groos MS, Brunelle F, Rahier J, Henquin JC, Dunne MJ, Jaubert F, Robert JJ, Nihoul-Fékété C, Vekemans M, Junien C, de Lonlay P. Congenital hyperinsulinism and mosaic abnormalities of the ploidy. J Med Genet 2006; 43:248-54.

166. Surti U, Hoffner L, Kolthoff M, Dunn J, Hunt J, Sniezek L, Macpherson T. Persistent gestational trophoblastic disease after an androgenetic/biparental fetal chimera: a case report and review. Int J Gynecol Pathol 2006;25:366-72.
167. Reed R, Beischel L, Schoof J, Johnson J, Raff M, Kapur R. Androgenetic/biparental mosaicism in an infant with hepatic mesenchymal hamartoma and placental mesenchymal dysplasia. Pediatr Dev Pathol (in press).

168. Lia C, Yang X, Pan M, Li D-Z. A 46,XY/46,XX mosaicism diagnosed at amniocentesis: another case report. Prenat Diagn 2008;28:65-6.

169. Yaron Y, Feldman B, Kramer RL, Kasperski SB, Vo T, Feldman GL, Johnson MP, Evans MI, Ebrahim SAD. Prenatal diagnosis of 46,XY/46,XX mosaicism: a case report. Am J Med Genet 1999;84:12-14.

170. Strain L, Warner JP, Johnston T, Bonthron DT. A human parthenogenetic chimaera Nat Genet 1995:11:164-9.

171. Robinson WP, Lauzon JL, Innes AM, Lim K, Arsovska S, McFadden DE. Origin and outcome of pregnancies affected by androgenetic/biparental chimerism. Hum Reprod 2007;22:1114-22.

172. Kaiser-Rogers KA, McFadden DE, Livasy CA, Dansereau J, Jiang R, Knops JF, Lefebvre L, Rao KW, Robinson WP. Androgenetic/biparental mosaicism causes placental mesenchymal dysplasia. J Med Genet 2006;43:187-92.

173. Surti U, Hill LM, Dunn J, Prosen T, Hoffner L. Twin pregnancy with a chimeric androgenetic and biparental placenta in one twin displaying placental mesenchymal dysplasia phenotype. Prenat Diagn 2005;25:1048-56.

174. Makrydimas G, Sebire NJ, Thornton SE, Zagorianakou N, Lolis D, Fisher RA. Complete hydatidiform mole and normal live birth: a novel case of confined placental mosaicism: case report. Hum Reprod 2002;17:2459-63.

175. Kotzot D. Review and meta-analysis of systematic searches for uniparental disomy (UPD) other than UPD 15. Am J Med Genet 2002:111A:366-75.

176. Kotzot D. Prenatal testing for uniparental disomy: indications and clinical relevance. Ultrasound Obstet Gynecol 2008;31:100-5.

177. Dennis NR, Veltman MWM, Thompson R, Craig E, Bolton PF, Thomas NS. Clinica findings in 33 subjects with large supernumerary marker(15) chromosomes and 3 subjects with triplication of 15q11-q13. Am J Med Genet 2006:140A:434-41.

178. Roberts SE, Maggouta F, Thomas NS, Jacobs PA, Crolla JA. Molecular and fluorescence in situ hybridization characterization of the breakpoints in 46 large supernumerary marker 15 chromosomes reveals an unexpected level of complexity. Am J Hum Genet 2003;73:1061-72.

179. Niu D-M, Pan Ch-Ch, Lin Ch-Y, Hwang PT, Chung M. Mosaic or chimera? Revisiting an old hypothesis about the cause of the $46, X X / 46, X Y$ hermaphrodite. J Pediat 2002;140:732-5.

180. Shaffer LG, Agan N, Goldberg JD, Ledbetter DH, Longshore JW, Cassidy SB. American College of Medical Genetics statement on diagnostic testing for uniparental disomy. Genet Med 2001;3:206-11.

\section{Save your favourite articles and useful searches}

Use the "My folders" feature to save and organise articles you want to return to quickly—saving space on your hard drive. You can also save searches, which will save you time. You will only need to register once for this service, which can be used for this journal or all BMJ Journals, including the BMJ. 